\title{
Refining the eruptive history of Ulleungdo and Changbaishan volcanoes (East Asia) over the last 86 kyrs using distal sedimentary records
}

Article

Accepted Version

Creative Commons: Attribution-Noncommercial-No Derivative Works 4.0

McLean, D., Albert, P. G., Suzuki, T., Nakagawa, T., Kimura, J.-I., Chang, Q. C., MacLeod, A., Blockley, S., Staff, R. A., Yamada, K., Kitaba, I., Haraguchi, T., Kitagawa, J., SG14 Project Members, and Smith, V. C. (2020) Refining the eruptive history of Ulleungdo and Changbaishan volcanoes (East Asia) over the last 86 kyrs using distal sedimentary records. Journal of Volcanology and Geothermal Research, 389. 106669. ISSN 0377-0273 doi:

https://doi.org/10.1016/j.jvolgeores.2019.106669 Available at https://centaur.reading.ac.uk/86408/

It is advisable to refer to the publisher's version if you intend to cite from the work. See Guidance on citing.

To link to this article DOI: http://dx.doi.org/10.1016/j.jvolgeores.2019.106669

Publisher: Elsevier 
copyright holders. Terms and conditions for use of this material are defined in the End User Agreement.

\section{www.reading.ac.uk/centaur}

\section{CentAUR}

Central Archive at the University of Reading

Reading's research outputs online 
1 REFINING THE ERUPTIVE HISTORY OF ULLEUNGDO AND 2 CHANGBAISHAN VOLCANOES (EAST ASIA) OVER THE LAST 386 KYRS USING DISTAL SEDIMENTARY RECORDS

4

5

6

DANIELLE MCLEAN*a, PAUL G ALBERTa, TAKEHIKO SUZUKI ${ }^{\text {, }}$, TAKESHI NAKAGAWA ${ }^{c}$, JUN-ICHI KIMURA ${ }^{d}$, QING CHANGd ${ }^{d}$ ALISON MACLEOD ${ }^{e, f}$, SIMON BLOCKLEYe, RICHARD A STAFFa,g, KEITARO YAMADAc, IKUKO KITABA $^{c}$, TSUYOSHI HARAGUCHI ${ }^{\mathrm{h}}$, JUNKO KITAGAWA', SG14 PROJECT MEMBERSj AND VICTORIA C SMITHa

a Research Laboratory for Archaeology and the History of Art, University of Oxford, Oxford, OX1 3TG, UK

${ }^{b}$ Department of Geography, Tokyo Metropolitan University, Tokyo, 192-0397, Japan

c Research Centre for Palaeoclimatology, Ritsumeikan University, Shiga, 525-8577, Japan

a Department of Solid Earth Geochemistry, Japan Agency for Marine-Earth Science and Technology, Yokosuka, Japan

e Department of Geography, Royal Holloway University of London, TW20 OEX, UK

${ }^{f}$ Department of Geography and Environmental Science, University of Reading, $R G 66 A B$, UK

g Scottish Universities Environmental Research Centre, University of Glasgow, East Kilbride, G75 OQF, UK

n Osaka City University, Osaka, 558-8585, Japan

i Fukui Prefectural Satoyama-Satoumi Research Institute, Wakasa, 919-1331 Japan

jwww.suigetsu.org

*Corresponding author: mclean.tephra@gmail.com

\section{Highlights:}

- Distal records show eruptions are more frequent and widespread

- At least 8 Changbaishan eruptions produced widespread ash over the last 86 kyrs

- Explosive eruption of Changbaishan at ca. 42.5 ka dispersed ash $>1000$ $\mathrm{km}$ 
35

36

37

38

39

40

41

42

43

44

45

46

47

48

49

50

51

52

- 4 Ulleungdo eruptions are now precisely dated using the Lake Suigetsu chronology

- U-Ym tephra is identified in Suigetsu and dated to $40,332-39,816$ IntCal13 yrs BP

\section{Abstract}

The eruptive histories of Ulleungdo (South Korea) and Changbaishan (North Korea/China border) volcanoes are not well constrained since their proximal stratigraphies are poorly exposed or largely inaccessible. However, determining the past behaviour of these volcanoes is critical since future eruptions are likely to disperse ash over some of the world's largest metropolitan regions. Alkaline tephra deposits erupted from both centres are routinely identified in marine cores extracted from the Sea of Japan, as well as high-resolution lacustrine records east of the volcanoes. Here, we review the distal ash occurrences derived from Ulleungdo and Changbaishan and provide new data from the Lake Suigetsu (central Honshu, Japan) sediment core, in order to provide a more complete and constrained eruption framework. The intensely-dated Lake Suigetsu archive provides one of the most comprehensive distal eruption records for both centres, despite being located ca. $500 \mathrm{~km} \mathrm{E}$ of Ulleungdo and ca. $1000 \mathrm{~km} \mathrm{SSE}$ of Changbaishan. The Suigetsu record is utilised to precisely date and geochemically fingerprint (using major, minor and trace element glass compositions) ash fall events that reached central Honshu. Here, we identify a new non-visible (cryptotephra) layer in the Suigetsu sediments, which reveals a previously unreported explosive event from Changbaishan at $42,750-42,323$ IntCal13 yrs BP (95.4\% confidence interval). This event is chronologically and 
61 geochemically distinct from the B-J (Baegdusan-Japan Basin) tephra reported

62 in the Sea of Japan (ca. $50 \mathrm{ka}$ ). Furthermore, we also confirm that the 63 widespread U-Ym tephra erupted from Ulleungdo reached central Japan, and is 64 herein dated to 40,332 - 39,816 IntCal13 yrs BP (95.4\% confidence interval). 65 This terrestrial ${ }^{14} \mathrm{C}$-derived age of the $\mathrm{U}-\mathrm{Ym}$ can be used to constrain the 66 chronology of marine records containing the same marker layer. This reviewed 67 and integrated tephrostratigraphic framework highlights the pivotal role that distal sedimentary records can play in evaluating the eruptive histories and hazard potential of Ulleungdo and Changbaishan.

71 Keywords: Ulleungdo, Changbaishan; Glass geochemistry; Eruption history; 72 Sedimentary archives; Lake Suigetsu

74 1. Introduction

76 Intraplate volcanoes Ulleungdo (South Korea) and Changbaishan (North 77 Korea/China border) are responsible for two of the largest Holocene eruptions 78 ( $\geq$ Volcanic Explosivity Index (VEI) 6; Newhall and Self, 1982) in East Asia, 79 blanketing large parts of Japan and the surrounding seas in ash (Figure 1; 80 Machida and Arai, 2003). Fine ash from the AD 946 'Millennium Eruption' (ME) 81 (Hakozaki et al., 2017; Oppenheimer et al., 2017) of Changbaishan has also 82 been identified ca. $9000 \mathrm{~km}$ from its source in northern Greenland (Sun et al., 83 2014a), which demonstrates the enormous potential of the volcano to cause 84 major disruption to airspace across the East Asian and Pacific region. Yet, the 85 complete eruptive histories of Ulleungdo and Changbaishan are not well 
largely inaccessible.

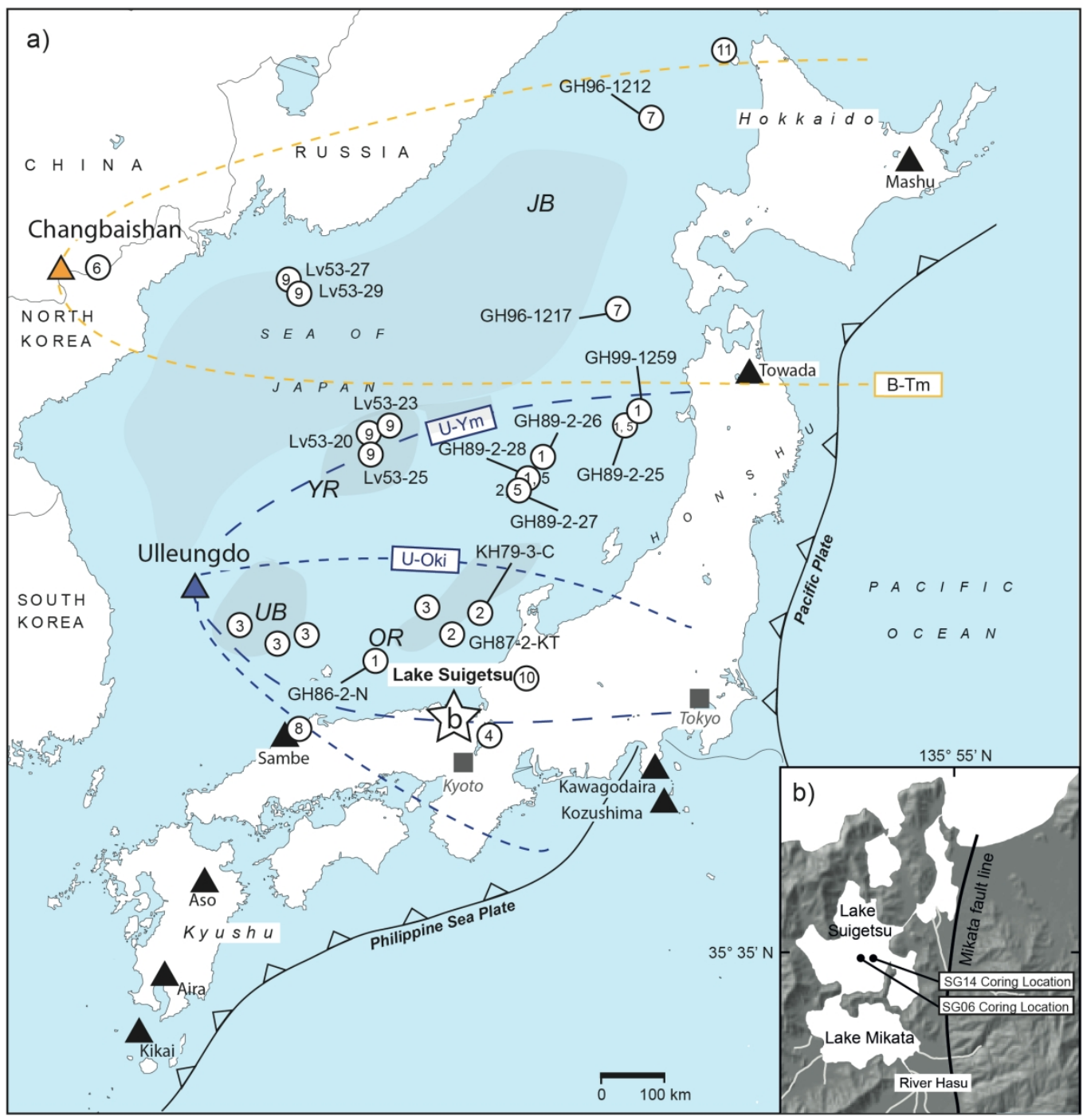

Figure 1. (a) Location of Ulleungdo (South Korea; blue triangle) and Changbaishan (North Korea/China; orange triangle) and other sources of Japanese tephras outlined in the text (black triangles). Distal sites mentioned in the text are marked by white circles; 1 = Marine cores; Lim et al. (2013); 2 = Marine cores; Arai et al. (1981); Chun et al. (2007); 3 = Marine cores; Chun et al. (2007); 4 = Lake Biwa; Nagahashi et al. (2004); 5 = Marine cores; Ikehera et al. (2004); 6 = Yuanchi Lake; Sun et al. (2018); 7 = Marine cores; Ikehara (2003); 8 = Lake Hane; Sawada et al. (1997); 9 = Marine cores; Derkachev et al. (in press); 10 = Hakusan volcano; Higashino et al. (2005); $11=$ Lake Kushu; Chen et al. (2016, 2019). A white star notates the location of Lake Suigetsu, and ocean basins are marked in grey $(\mathrm{JB}=$ Japan Basin; $\mathrm{YR}=$ Yamato Rise; $\mathrm{OR}=$ Oki Ridge; UB = Ulleungdo Basin). Dispersal boundaries of the B-Tm (AD 946; Oppenheimer et al., 2017), U-Oki (ca. $10 \mathrm{ka}$ ) and U-Ym (ca. $40 \mathrm{ka}$ ) are marked by dashed lines (B-Tm and U-Oki as defined by Machida and Arai, 2003). (b) Location of Lake Suigetsu, which is the largest of the five Mikata lakes, adjacent to Wakasa Bay. The positions of coring campaigns SG06 and SG14 are marked on Lake Suigetsu (modified after Nakagawa et al., 2005). 
105 It is likely that proximal evidence of older eruptions, especially those of low- to 106 mid-intensity, have been destroyed, or are now completely buried, following 107 more recent large magnitude Holocene events. At Changbaishan clear 108 depositional breaks and soil horizons are not well documented within proximal 109 eruption successions (e.g., Chen et al., 2016; Sun et al., 2017), making it 110 unclear how many eruption deposits are preserved.

\section{1}

112 Distal sedimentary records (e.g., marine and lacustrine sequences) have 113 proved very important archives of past explosive eruptions, and can be used to 114 help constrain the frequency and dispersal of tephra-forming events (e.g., Wulf 115 et al., 2004; Albert et al., 2013; 2018; Smith et al., 2013; Tomlinson et al., 2014; 116 Ponomareva et al., 2018). Ulleungdo and Changbaishan are the only sources 117 known to have dispersed alkaline tephra across Japan (Machida and Arai, 118 2003; Kimura et al., 2015; Albert et al., 2019), and their distal deposits can be 119 easily discriminated from other intraplate sources in the back-arc (e.g., Doki and 120 Jeju volcanoes; Brenna et al., 2014). Tephra layers preserved in marine cores 121 extracted from the Sea of Japan (Oki ridge, Yamato and Japan basins; Figure 122 1), indicate that both Ulleungdo and Changbaishan have been very active 123 during the Late Quaternary, however the number and precise timing of these 124 events remains uncertain. This is partly since successive eruption deposits are 125 difficult to geochemically distinguish, and because marine cores in some 126 localities are susceptible to reworking processes (e.g., turbidites; Albert et al., 127 2012; Cassidy et al., 2014), and often cannot be precisely dated (i.e., due to 128 variations in the marine radiocarbon reservoir; Ikehara et al., 2013). 
130 In order to provide new insight into the eruptive histories of Ulleungdo and

131 Changbaishan, this study provides a detailed review of the distal occurrences of

132 alkaline ash deposited in sedimentary records (marine and lacustrine cores)

133 spanning the last 86 kyrs (i.e., post-dating the widespread Aso-4 tephra that is

134 dated to $86.4 \pm 1.1 \mathrm{ka}$ using the ${ }^{40} \mathrm{Ar} /{ }^{39} \mathrm{Ar}$ method; Albert et al., 2019). We also

135 provide new tephra data from the intensely-dated Lake Suigetsu archive

136 (central Honshu, Japan), a record that has significant potential to develop a

137 comprehensive eruption history for both centres (despite being located $500 \mathrm{~km}$

138 E of Ulleungdo and $1000 \mathrm{~km}$ SSE of Changbaishan). Using the lake sediments,

139 we identify and geochemically characterise two new ash layers erupted from

140 Ulleungdo and Changbaishan, allowing these eruptive events to be precisely

141 dated for the first time. New trace element data are also generated for the

142 previously identified marker layers preserved as cryptotephra in the Holocene

143 sediments (McLean et al., 2018), offering new possibilities to discriminate

144 between successive eruption deposits. This reviewed and integrated distal

145 eruption framework for Ulleungdo and Changbaishan permits critical new insight

146 into the hazard potential of these active centres.

148 2. Regional setting and proximal volcanic deposits

150

\subsection{Ulleungdo Island, South Korea}

151

152 Ulleungdo Island (12 km x $10 \mathrm{~km})$ is the sub-aerial portion of a Quaternary

153 stratovolcano located in the mid-western part of the Sea of Japan $\left(37^{\circ} 30^{\prime} \mathrm{N}\right.$,

$\left.154130^{\circ} 52^{\prime} \mathrm{E}\right), 130 \mathrm{~km}$ east of the Korean Peninsula (Figure 1; Kim, 1985). 
155 Ulleungdo is the youngest volcano in the back-arc basin, and is known to have 156 erupted intermittently from the Pliocene until the mid-Holocene (Kim et al., 157 1999; Okuno et al., 2011; Im et al., 2012). Nari caldera is located at the centre 158 of the island (2.8 $\mathrm{km}$ in diameter) and is the source of the most recent phase of 159 activity (< $19 \mathrm{ka}$; Kim et al., 2014), erupting rocks that range from alkali basalt to 160 trachyandesite in composition (Kim, 1985; Brenna et al., 2014; Chen et al., 161 2018).

162

163 The most recent activity of Ulleungdo is exposed at several outcrops near or 164 within Nari caldera. Machida et al. (1984) defined seven pyroclastic units at 165 extra-caldera outcrops in the north (named in ascending order: $U-7$ to $U-1$ ), 166 which are comprised of trachytic or phonolitic ash and pumice that were 167 emplaced as fall deposits and/or by pyroclastic flows (Figure 2). The Holocene 168 stratigraphy (U-4 to U-2) was further subdivided by Okuno et al. (2011) and 169 Shiihara et al. (2011) at exposures in the southeast, where the units have also 170 been geochemically analysed and radiocarbon dated (Figure 2). Two 171 widespread Japanese tephra marker layers erupted from volcanoes of southern 172 Kyushu Island are found within the soils that formed between these pumice 173 falls, and are named the Aira-Tanzawa (AT; ca. 30.0 ka) and Kikai-Akahoya (K174 Ah; ca. $7.3 \mathrm{ka}$ ) ash. The $U-7$ to $U-5$ eruption units are stratigraphically identified 175 below the AT tephra, and the K-Ah ash is positioned between the U-3 and U-2 176 eruptions (Shiihara et al., 2011). Radiocarbon dates obtained from buried soils 177 (ca. $2 \mathrm{~cm}$ thick) between units, and charred tree material preserved in the 178 Holocene deposits suggest that the U-3 eruption occurred ca. 8.3 or 9 ka BP, 179 respectively, and the $\mathrm{U}-2$ eruption at ca. $5.6 \mathrm{ka} \mathrm{BP}$. 


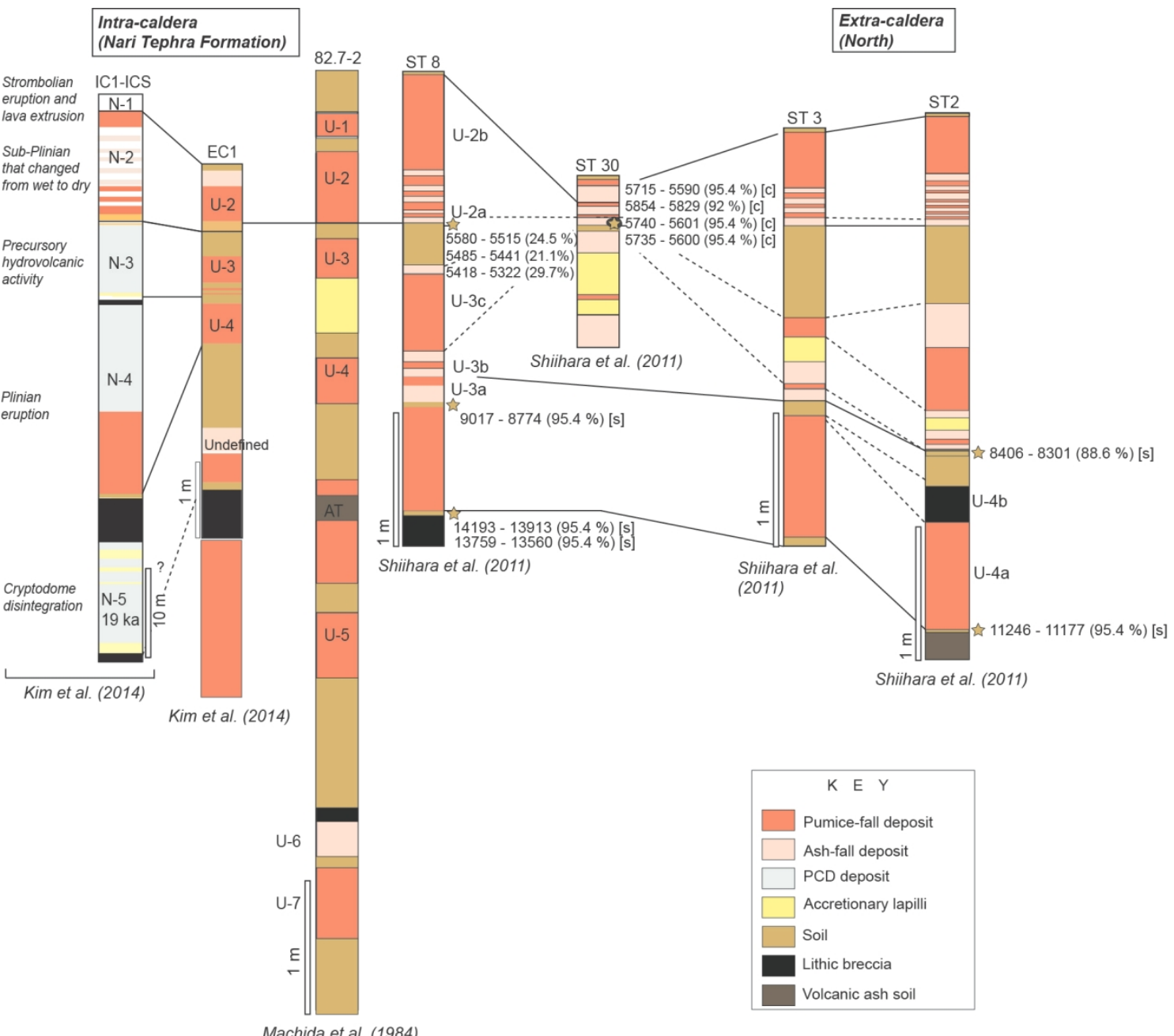

Figure 2. Sedimentological and stratigraphic characteristics of the intra- and extra183 caldera outcrops on Ulleungdo Island (Machida et al., 1984; Okuno et al., 2010; 184 Shiihara et al., 2011; Kim et al., 2014). The radiocarbon ages (s = soil; c = charcoal) 185 reported by Okuno et al. (2010) have been recalibrated using IntCal13 (IntCal13 yrs BP). Two Japanese tephra layers erupted from volcanoes in Kyushu are identified within the soils of the extra-caldera sequences, which include the AT (30 ka) and K-Ah 189 (7.3 ka) ash.

191 to be geochemically similar (Machida et al., 1984; Martin Jones, 2012; Shiihara 192 et al., 2011). Slight geochemical differences between some subunits are 193 reported by Shiihara et al. (2011), who show that U-4a and U-3c contain glass 194 with lower $\mathrm{Al}_{2} \mathrm{O}_{3}$ and higher $\mathrm{CaO}$ and $\mathrm{FeO}^{\top}$. Furthermore, subunits U-3a and U- 
$1952 \mathrm{a}$ are characterised by slightly lower $\mathrm{CaO}, \mathrm{TiO}_{2}$ and $\mathrm{FeO}^{\top}$ contents compared

196 to the other units.

197

198 Intra-caldera outcrops at Nari are ca. $70 \mathrm{~m}$ thick, and are composed of un199 welded pyroclastic and epiclastic deposits spanning the last 19 kyrs (Figure 2; 200 Im et al., 2012; Kim et al., 2014). This sequence is named the Nari Tephra 201 Formation, and consists of five key eruptive units (in ascending order, N-5 to N202 1), some of which exhibit signs of weathering and soil formation (Figure 2). 203 Several radiocarbon ages have been obtained from this formation by Im et al. 204 (2012), which have been used to correlate the intra- and extra-caldera 205 Holocene deposits (U-4 to U-2, and N-4 to N-2) as shown in Figure 2. Kim et al. 206 (2014) have proposed a detailed succession of eruption styles for the last 19 207 ka, and suggest that only a few of the events generated sustained eruption 208 columns or pyroclastic density current (PDC) deposits large enough to overtop 209 the caldera wall, and therefore extra-caldera sequences may underestimate the 210 eruption frequency.

214 Changbaishan (also referred to as Baitoushan, Paektusan, or Hakutozan) is an 215 intraplate stratovolcano situated on the border of North Korea and China $216\left(41^{\circ} 00^{\prime} \mathrm{N}, 128^{\circ} 03^{\prime} \mathrm{E}\right.$; Figure 1$)$, located on a Neogene trachybasalt lava shield 217 (the Gaema Plateau). Activity at Changbaishan began in the Middle 218 Pleistocene, and has been divided into three main episodes: early shield 219 building, middle cone construction, and a late explosive stage (Wei et al., 2007; 2013). The most recent of which (<20 ka) culminated with the caldera-forming 
221 Millennium Eruption (ME; VEI 7) which ejected ca. $100 \mathrm{~km}^{3}$ of tephra (Dense

222 Rock Equivalent ca. $25 \mathrm{~km}^{3}$ ), blanketing the northernmost regions of Japan in 223 ash (Horn and Schmincke, 2000; Zou et al., 2010; Wei et al., 2013; Sun et al., 224 2014b; McLean et al., 2016) and injecting $45 \mathrm{Tg}$ of sulphur into the atmosphere 225 (lacovino et al., 2016). This eruption produced a ca. $4.5 \mathrm{~km}$ wide caldera, which 226 today contains Lake Tianchi (meaning "Heavenly Lake"; Machida et al., 1990).

227 The age of the $M E$ has been precisely dated to $A D 946$, by combining 228 dendrochronology with the presence of a closely related (AD 994) 'Miyake 229 event' (pronounced radiocarbon peak) preserved in charred tree deposits 230 (Hakozaki et al., 2017; Oppenheimer et al., 2017). The hazard potential of 231 Changbaishan is considerable and is particularly concerning given that there 232 has been recent seismic unrest at the crater (Stone, 2010; Xu et al., 2012; Wei 233 et al., 2013).

234

235 The most comprehensively studied proximal outcrop at Changbaishan is at 236 Twianwenfeng peak, which is on the northern Chinese flank of the summit (e.g., 237 Chen et al., 2016; Pan et al., 2017; Sun et al., 2017; 2018). There are many 238 inconsistent interpretations of these Late Quaternary eruption deposits, even 239 amongst those assigned to the ME (see Pan et al., 2017). Sun et al. (2017) 240 identify and geochemically characterise five sequential deposits (oldest to 241 youngest, named NS-1 to NS-5) at Twianwenfeng peak, and suggest that the 242 three uppermost units (NS-3 to NS-5) are associated with the ME, due to the 243 geochemical (major element glass chemistry) overlap with distal ash deposits, 244 and that no depositional break is evident between units NS-4 and NS-5. This is 245 in contrast to other studies that suggest that the youngest unit (NS-5) may 
246 correlate to post-ME events, which are suggested by historical records in AD 2471668 or AD 1702 (Cui et al., 1995; Liu et al., 1998).

248

249 The ME had two explosive phases, with the initial main phase (ca. 95\% by 250 volume) associated with a ca. $25 \mathrm{~km}$-high Plinian column, producing a 251 widespread rhyolitic pumice fall unit (Machida et al., 1990; Horn and 252 Schmincke, 2000), which equates to NS-3 of Sun et al. (2017). This fall unit is 253 overlain by partially-welded PDC deposits attributed to the partial collapse of the 254 Plinian column. Trachytic magma was erupted in a late phase of the eruption 255 (i.e., NS-4 and NS-5), forming moderately welded PDC units that overlie the 256 rhyolitic fall and PDC deposits (Horn and Schmincke, 2000). Chen et al. (2016) 257 report trace element compositions for the ME at Twianwenfeng peak (therein 258 named units $\mathrm{C}-3$ to $\mathrm{C}-1$ ), and show that the rhyolitic fall deposits (C-3 to C-2) 259 had higher contents of incompatible trace elements (e.g., Th, Ta, Nd, Y) and 260 lower contents of compatible elements (e.g., Ba, Sr) relative to the upper 261 trachyte unit (C-1).

263 Sun et al. (2017) identify two pre-ME pyroclastic fall deposits at Twianwenfeng 264 peak, NS-1 (grey fall unit) and NS-2 (yellow fall unit), which are compositionally 265 distinct from the ME deposits. These units are estimated to have been erupted 266 between $4-5$ ka based on ${ }^{40} \mathrm{Ar} /{ }^{39} \mathrm{Ar}$, uranium series disequilibrium, ${ }^{14} \mathrm{C}$ and 267 optically stimulated luminescence (OSL) methods (Liu et al., 1998; Wan and 268 Zheng, 2000; Wang et al., 2001; Yang et al., 2014). 
270 A large "lava flow" landform, named the Qixiangzhan Comendite that is $5 \mathrm{~km}$

271 long and $400-800 \mathrm{~m}$ wide, is observed on the northern summit of Changbaishan

272 (Yang et al., 2014; Sun et al., 2017). This is widely considered as another pre-

$273 \mathrm{ME}$ event, although ${ }^{40} \mathrm{Ar} /{ }^{39} \mathrm{Ar}$ ages generated from this deposit span several 274 thousand years (e.g., Singer et al., 2014; Yang et al., 2014) and its stratigraphic 275 relationship to the units preserved at Twianwenfeng peak is unclear (Sun et al., 276 2017). Major element glass compositions of the Qixiangzhan comendite overlap 277 with those of the rhyolitic phase of the ME (Sun et al., 2018).

278

\subsection{Distal marine and lacustrine tephra records}

280

281 The Sea of Japan (East Sea) is a semi-enclosed marginal sea located between 282 the Japanese islands and the Asian continent, and is the product of the rear-arc 283 extension (Figure 1). Due to the prevailing westerly winds, tephra erupted from 284 Ulleungdo and Changbaishan is typically dispersed to the east and deposited in 285 the surrounding marine basins (Arai et al., 1981; Chun et al., 1997, 2007; 286 Ikehara, 2003; Machida and Arai, 2003; Ikehara et al., 2004; Lim et al., 2013, 287 2014; Derkachev et al., in press). Furthermore, several Japanese tephra layers 288 erupted from volcanoes on Kyushu Island have been dispersed to, and 289 deposited in the Sea of Japan, including the K-Ah (Kikai), AT (Aira), SAN1 290 (Kuju) and Aso-4 eruption deposits (Machida and Arai, 2003; Albert et al., 291 2019). The marine sediments across the Sea of Japan are characterised by 292 alternations of light and dark coloured sediments, which have been attributed to 293 millennial-scale palaeoenvironmental changes associated with changes in the 294 East Asian summer monsoon (Tada, 1999; Ikehara, 2003). These organic rich 
295 dark-layers are commonly used to date tephra layers that are preserved in the 296 marine sediments (Tada et al., 1999). It has proved very difficult to correlate 297 between the proximal eruption successions exposed at Ulleungdo and 298 Changbaishan with those in distal records (Shiihara et al., 2011; Kim et al., 299 2014; Chen et al., 2016; Pan et al., 2017). Typically, only the largest Holocene 300 eruptions that reached the Japanese islands have been correlated to specific 301 eruption units within proximal stratigraphies of these two volcanoes.

302

303 The most widespread tephra layer from Changbaishan is associated with the 304 AD $946 \mathrm{ME}$, and is distally named the Baegdusan-Tomakomai (B-Tm tephra). 305 The B-Tm tephra was named and characterised using glass refractive indices 306 and major element compositions (Machida and Arai, 1983; McLean et al., 2016) 307 at a distal type-locality in Tomakomai Port, Hokkaido (northern Japan), where it 308 was identified above the Tarumai-c (ca. 50 BC) and below the Tarumai-b (AD 309 1667) tephra layers from the nearby Tarumae volcano (Machida and Arai, 310 1983). The B-Tm tephra has since been identified in numerous marine, 311 lacustrine and archaeological sequences across northern Japan, northeast 312 China and coastal regions of Russia (see Sun et al., 2014b; McLean et al., 313 2016) and B-Tm glass shards have been identified in the Greenland ice cores 314 (Sun et al., 2014a).

316 The most widespread tephra erupted from Ulleungdo is the Ulleung-Oki (U-Oki), 317 which is correlated to the proximal U-4 deposits on the island (Machida et al., 318 1984; Okuno et al., 2010; Shiihara et al., 2011; Smith et al., 2011; Kim et al., 319 2014). The U-Oki tephra has been identified in several marine cores in the Sea 
320 of Japan, and in archives on the islands of Japan, including Lake Biwa, Lake

321 Suigetsu and Lake Hane (Chun et al., 1997; Domitsu et al., 2002; Nagahashi et

322 al., 2004; Smith et al., 2011; Figure 1). As outlined further below, several of

323 these archives contain a younger phonolitic/trachytic ash that post-dates the $U$ -

324 Oki tephra, and are thought to be distal correlatives of the U-3 eruption of 325 Ulleungdo.

326

327 One of the most comprehensive records of East Asian volcanism is the Lake 328 Suigetsu sedimentary archive, which is located ca. $500 \mathrm{~km} \mathrm{E}$ of Ulleungdo and 329 ca. $1000 \mathrm{~km}$ SSE of Changbaishan $\left(35^{\circ} 35^{\prime} 0^{\prime \prime} \mathrm{N}, 135^{\circ} 53^{\prime} 0^{\prime \prime} \mathrm{E}, 0 \mathrm{~m}\right.$ above present 330 sea level; Figure 1). The sequence spans approximately 150 ka (Nakagawa et 331 al., 2012), and contains a detailed record of visible and non-visible 332 (cryptotephra) layers derived from Ulleungdo and Changbaishan eruptions, as 333 well as over thirty visible tephra layers erupted from sources that span the 334 length of Japan (Smith et al., 2013; McLean et al., 2016, 2018; Albert et al., $3352018,2019)$. Despite the difficulties of identifying non-visible layers in a 336 productive arc setting, cryptotephra layers are precisely preserved and 337 identified in Lake Suigetsu, partially due to its unique hydrological setting. 338 Suigetsu is a tectonic lake, adequately situated away from the large calderas in 339 Hokkaido and Kyushu, and so is not inundated with locally sourced volcanic 340 glass which would preclude the identification of cryptotephra layers deposited 341 during large distally occurring eruptions. Furthermore, no rivers flow directly into 342 Lake Suigetsu (Figure 1b) with the water level controlled by input into the other 343 connected lakes. The fine-grain sedimentation in the lake is often interrupted by 344 deposits of coarse volcanic ash that fall through the water column. 
346 Since the Lake Suigetsu sediments have been extensively radiocarbon $\left({ }^{14} \mathrm{C}\right)$

347 dated, and seasonal laminae (varves) are preserved between ca. 10 and $50 \mathrm{ka}$ 348 (Staff et al., 2011; Bronk Ramsey et al., 2012; Marshall et al., 2012; Schlolaut et 349 al., 2012), eruptions within the radiocarbon timeframe can be precisely dated if 350 their associated tephra layers are identified. The Lake Suigetsu 351 tephrostratigraphic record is therefore utilised in this study to precisely date ash 352 fall events of Ulleungdo and Changbaishan that reached central Honshu, and 353 integrate their tephrostratigraphies.

\section{Tephra identification and analytical methods}

\subsection{New tephra identification in Lake Suigetsu}

359 The high-resolution and intensely dated sediments of Lake Suigetsu (SG06 and 360 SG14 cores) have been re-investigated for the presence of thin (i.e., sub 361 millimetre in thickness) and cryptotephra layers, in order to supplement the 362 visible tephrostratigraphy as introduced above, and published by Smith et al., 363 (2011, 2013) and Albert et al. (2018, 2019). Cryptotephra extraction procedures 364 (modified from Turney, 1998; Blockley et al., 2005) were undertaken through 365 the $12 \mathrm{~m}$ of Holocene sediments ( $\leq 10 \mathrm{ka}$; McLean et al., 2016, 2018) and more 366 recently the $14 \mathrm{~m}$ of annually laminated (varved) sediments dating to between 367 ca. 50 and $30 \mathrm{ka}$, These sections were chosen for analysis as they were 368 expected to contain low-background levels of volcanic glass, which would not 369 obscure primary cryptotephra peaks (see McLean et al., 2018). On average, 
370 through these investigated sediments cryptotephra layers are four times more

371 frequently preserved than visible ash layers. Identified tephra layers in the

372 Suigetsu sediments are named, and are referred to using their SG06 373 (correlation model 06 June '17) or SG14 (correlation model 30 May '16) core 374 composite depth(s) in $\mathrm{cm}$.

375

376 The Suigetsu Bayesian age model (Staff et al., 2011; Bronk Ramsey et al., 377 2012) was used to determine the age for ash layers preserved in the sediments. 378 The composite Suigetsu sedimentary sequence was modelled on to the 379 IntCal13 timescale (Reimer et al., 2013) implementing three successive cross380 referenced Poisson-process ('P_Sequence') depositional models using OxCal 381 (ver. 4.3; Bronk Ramsey, 2008, 2017). These include 775 AMS ${ }^{14} \mathrm{C}$ dates 382 obtained from terrestrial plant macrofossils from the upper $38 \mathrm{~m}$ (SG06383 Composite Depth (CD) of the SG93 and SG06 cores (Kitagawa and van der 384 Plicht, 1998a; 1998b, 2000; Staff et al., 2011, 2013a, 2013b; Bronk Ramsey et 385 al., 2012) and varve counting between 12.88 and 31.67m SG06 CD (Marshall et 386 al., 2012; Schlolaut et al., 2012). Outside of the varve-counted depth interval, 387 SG06 event-free depth(s) (EFD, ver. 29th Jan '11) were used within the age 388 model, which excludes instantaneous deposits > $5 \mathrm{~mm}$ in thickness, (e.g., 389 floods, and tephra deposits; Staff et al., 2011; Schlolaut et al., 2012).

3.2. Major and trace element analysis of the glass shards

393 Major and minor element compositions of individual glass shards extracted from 394 the Suigetsu visible and cryptotephra layers were measured using a JEOL-8600 
395 wavelength-dispersive electron microprobe (WDS-EMP) at the Research 396 Laboratory for Archaeology and History of Art (RLAHA), University of Oxford. All 397 glass analyses used an accelerating voltage of $15 \mathrm{kV}$, beam current of $6 \mathrm{nA}$ and $39810 \mu \mathrm{m}$-diameter beam. Peak counting times were $12 \mathrm{~s}$ for $\mathrm{Na}, 50 \mathrm{~s}$ for $\mathrm{Cl}, 60 \mathrm{~s}$ 399 for $\mathrm{P}$, and for $30 \mathrm{~s}$ for all other elements. The electron microprobe was 400 calibrated using a suite of mineral standards, and the PAP absorption correction 401 method was applied for quantification. The accuracy and precision of these data 402 were assessed using analyses of the MPI-DING reference glasses from the 403 Max Plank Institute (Jochum et al., 2006), which were run as secondary 404 standards. Analyses of these secondary standards lie within the standard 405 deviation of the preferred values and are presented in the Supplementary 406 Material. All these data were filtered to remove non-glass analyses, and those 407 with low analytical totals $<93 \%$. The raw values were normalised (to $100 \%$ ) for 408 comparative purposes and to account for variable glass hydration, and are 409 presented as such in all tables and figures.

411 Trace element compositions of the glass shards $>25 \mu \mathrm{m}$ (i.e. large enough for 412 analysis) were measured by laser ablation inductively-coupled plasma mass 413 spectrometry (LA-ICP-MS) at the Department of Solid Earth Geochemistry, 414 Japan Agency for Marine-Earth Science and Technology (JAMSTEC). The 415 analytical equipment used include the deep-ultraviolet $(200 \mathrm{~nm})$ femtosecond 416 laser ablation system (DUV-FsLA) of OK-Fs2000K (OK Laboratory, Tokyo, 417 Japan) connected to the modified high-sensitivity sector field ICP-MS of 418 Element XR (Thermo Scientific, Bremen, Germany). All analyses used a $25 \mu \mathrm{m}$ 419 crater diameter and depth, and conditions followed those reported by Kimura 
420 and Chang (2012). Ten major elements including $\mathrm{P}_{2} \mathrm{O}_{5}$ and 33 trace elements

421 were analysed for each sample, and were also run alongside several MPI-DING

422 reference glasses (Jochum et al., 2006), and the BHVO-2G standard provided

423 by the United States Geological Survey. Accuracies of the BHVO-2G glass 424 analyses are typically $<3 \%$ for most elements, $<5 \%$ for Sc, Ga, Sm, Eu, Gd, $425 \mathrm{U}$ and $<10 \%$ for $\mathrm{Ni}, \mathrm{Cu}$, Lu. Full trace element datasets and secondary 426 standard analyses are provided in the Supplementary Material.

\section{Results}

\subsection{Suigetsu tephrostratigraphy}

431

432 To date, thirty-three visible tephra layers (Smith et al., 2011, 2013; Albert et al., 433 2018; 2019; McLean et al., 2016, 2018) and thirty-four cryptotephra layers 434 (between 50 to $30 \mathrm{ka}$, and > $10 \mathrm{ka}$; McLean et al., 2018) have been identified 435 and geochemically fingerprinted in the Lake Suigetsu sediments. The 436 distinctively high alkali content of glass shards $\left(\mathrm{Na}_{2} \mathrm{O}+\mathrm{K}_{2} \mathrm{O}=>9\right.$ wt. \%; Figure 437 3) of eight of these tephra layers indicates that they are not from the Japanese 438 arc volcanoes (Machida and Arai, 2003; Kimura et al., 2015; Albert et al., 2019), 439 and are correlated by McLean et al. $(2016,2018 ; n=6)$ and herein $(n=2)$ to 440 eruptions from Ulleungdo and Changbaishan. 

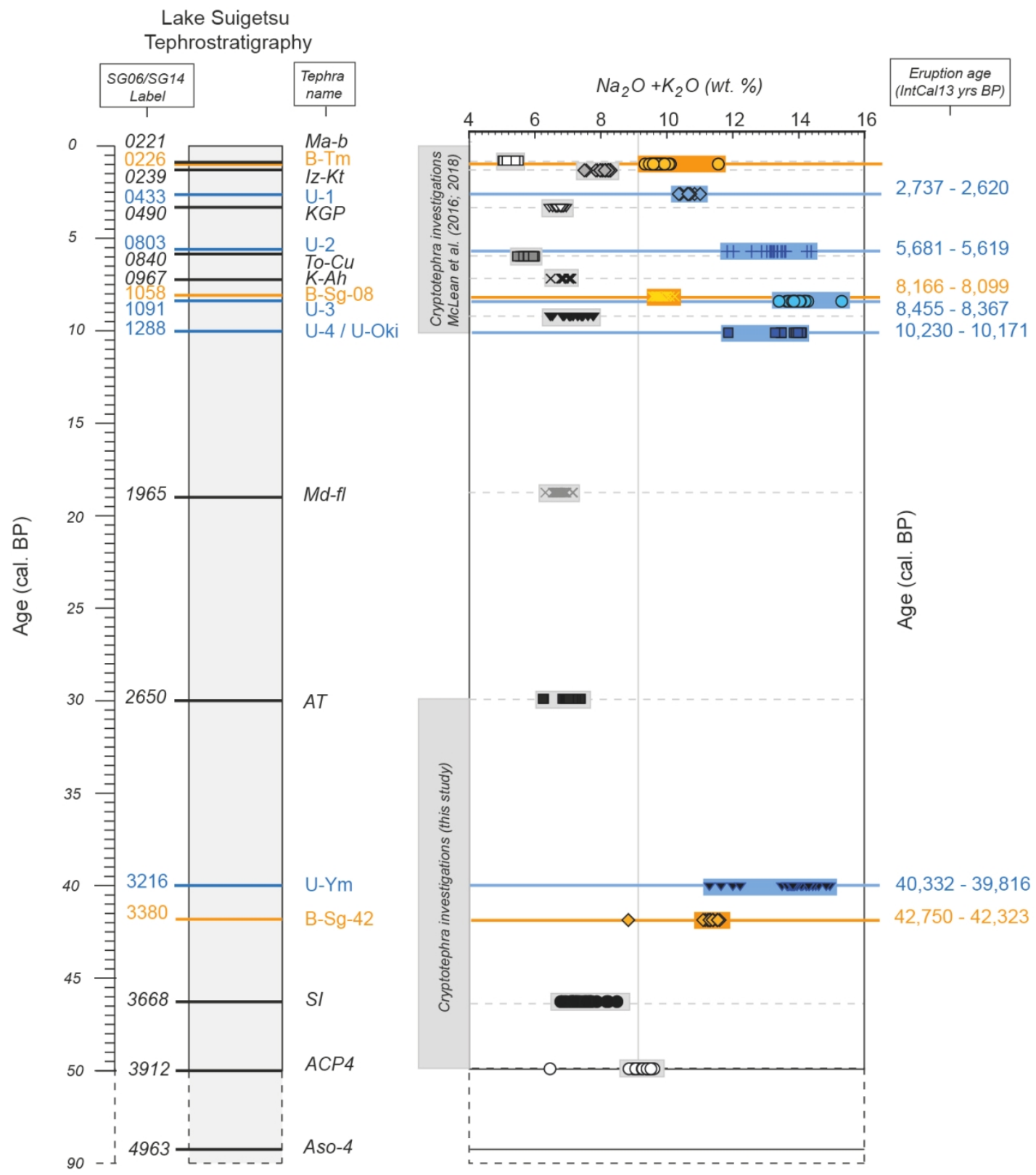

442 Figure 3. The composite Lake Suigetsu tephrostratigraphy and the positioning of 443 Ulleungdo (blue lines), Changbaishan (orange) and other key Japanese (black/grey) 444 tephra layers preserved through the sequence (Smith et al., 2013; McLean et al., 2016, 445 2018; Albert et al., 2018; 2019). The glass shard total alkali content $\left(\mathrm{Na}_{2} \mathrm{O}+\mathrm{K}_{2} \mathrm{O}\right)$ of 446 these layers is also plotted against eruption age, with Ulleungdo and Changbaishan 447 tephras containing > 9 wt. \%. 
4.1.1. New Ulleungdo and Changbaishan deposits

449

450 As part of detailed cryptotephra investigations through the Suigetsu sediments 451 dated between ca. 50 to $30 \mathrm{ka}$, two new alkaline ash layers named SG14-3380 452 and SG14-3216 have been identified. These are positioned between the 453 Sambe-lkeda (46.4 ka; Albert et al., 2019) and AT (30.0 ka; Smith et al, 2013; 454 Albert et al., 2019) tephras (Figure 3; Table 1). SG14-3380 is a highly 455 concentrated cryptotephra horizon erupted from Changbaishan, and contains 456 over 18,000 shards per gram of dried sediment (Figure 4a.). This eruption is 457 dated to between 42,750 - 42,323 IntCal13 yrs BP (95.4 \% confidence interval) 458 using the Suigetsu age model. SG14-3216 is a thin visible (ca. $1 \mathrm{~mm}$ ) white ash 459 layer (Figure 4b) that is ca. $1.6 \mathrm{~m}$ above SG14-3380, and represents an 460 Ulleungdo eruption between 40,332 - 39,816 IntCal13yrs BP (95.4\% 461 confidence interval).

462

463 4.1.2. Previous identifications of Ulleungdo and Changbaishan deposits 464

465 As previously reported by McLean et al. (2018), the Lake Suigetsu Holocene 466 tephrostratigraphy contains three eruptions from Ulleungdo: SG06-1288, SG144671091 and SG14-0803 that are dated to 10,230 - 10,171 IntCal13 yrs BP, 8,455 $468-8,367$ IntCal13 yrs BP and 5,681 - 5,619 IntCal13 yrs BP (95.4 \% confidence 469 interval), respectively (Table 1; Figure 3; Smith et al., 2011; McLean et al., 470 2018). A younger ash layer that also has glass compositions that are similar to 471 eruptions from Ulleungdo (SG14-0433) is dated to 2,737 - 2,620 IntCal13 yrs 472 BP (Table 1; Figure 3). 
474 Table 1. Summary of the Ulleungdo and Changbaishan derived tephra layers identified 475 in the Lake Suigetsu (SG06 \& SG14) sequence (in bold and shaded grey), along with 476 their stratigraphic positioning relative to key Japanese marker layers. Tephra 477 correlations for SG06 tephra layers are discussed by Smith et al. (2013), McLean et al. 478 (2016) and Albert et al. $(2018,2019)$ and SG14 tephra layers are correlated in McLean 479 et al. (2018, this study).

480

\begin{tabular}{|c|c|c|c|c|c|}
\hline SG Label & Tephracode & Tephra name & Source volcano & Source location & $\begin{array}{c}{ }^{14} \text { Codate (AD/ IntCal13 } \\
\text { yrs BP) }\end{array}$ \\
\hline SG14-0221 & Ma-b & Mashu-b & Mashu & Kurile arc, Japan & AD $960-992^{1}$ \\
\hline SG06-0226 & B-Tm & Baegdusan-Tomakomai & Changbaishan & North Korea/ China & AD946 2 \\
\hline SG14-0239 & $\mathrm{Iz}-\mathrm{Kt}$ & Izu-Kozushima-Tenjosan & Kozushima & Izu arc, Japan & $\operatorname{AD} 838^{3}$ \\
\hline SG14-0433 & U-1 & Ulleung-1 & Ulleungdo & South Korea & 2,737- 2,201 \\
\hline SG14-0490 & KGP & Kawagodaira Pumice & Kawagodaira & Izu arc, Japan & $3,227-3,129^{1}$ \\
\hline SG14-0803 & U-2 & Ulleung-2 & Ulleungdo & South Korea & $5,681-5,619^{1}$ \\
\hline SG14-0840 & To-Cu & Towada-Chuseri & Towada & Northern Honshu, Japan & $5,986-5,899^{1}$ \\
\hline SG06-0967 & K-Ah & Kikai-Akohoya & Kikai & Southem Kyushu, Japan & $7,307-7,196^{1}$ \\
\hline SG14-1058 & B-Sg-08 & Baegdusan-Suigetsu-08 & Changbaishan & North Korea/ China & $8,166-8,099^{1}$ \\
\hline SG14-1091 & u-3 & Ulleung-3 & Ulleungdo & South Korea & $8,455-8,367^{1}$ \\
\hline SG14-1185 & 1185 & - & - & - & $9,372-9,301^{1}$ \\
\hline SG06-1288 & U-Okj / U-4 & Ulleung-4/ Ulleung-Okj & Ulleungdo & South Korea & $10,230-10,171^{1}$ \\
\hline SG06-1965 & Md-fl & Sambe-Midorigaoka fl & Sambe & SWJapan & $19,631-19,471^{4}$ \\
\hline SG06-2650 & AT & Aira-Tanzawa & Aira & Southem Kyushu, Japan & $30,174-30,078^{4}$ \\
\hline SG14-3216 & U-Ym & Ulleung-Yamato & Ulleungdo & South Korea & $40,332-39,816^{5}$ \\
\hline SG14-3380 & B-Sg-42 & Baegdusan-Suigetsur-42 & Changbaishan & North Korea/ China & $42,750-42,323^{5}$ \\
\hline SG06-3668 & $\mathrm{SI}$ & Sambe-lkeda & Sambe & SWJapan & $46,566-46,162^{4}$ \\
\hline SG06-3912 & ACP4 & Aso-Central Pumice 4 & Aso & Central Kyushu, Japan & $50,311-49,637^{4}$ \\
\hline SG06-4963 & Aso-4 & Aso-4 & Aso & Central Kyushu, Japan & $86.4 \pm 1.1{ }^{40} \mathrm{Ar} /{ }^{39} \mathrm{Ar}^{4}$ \\
\hline
\end{tabular}
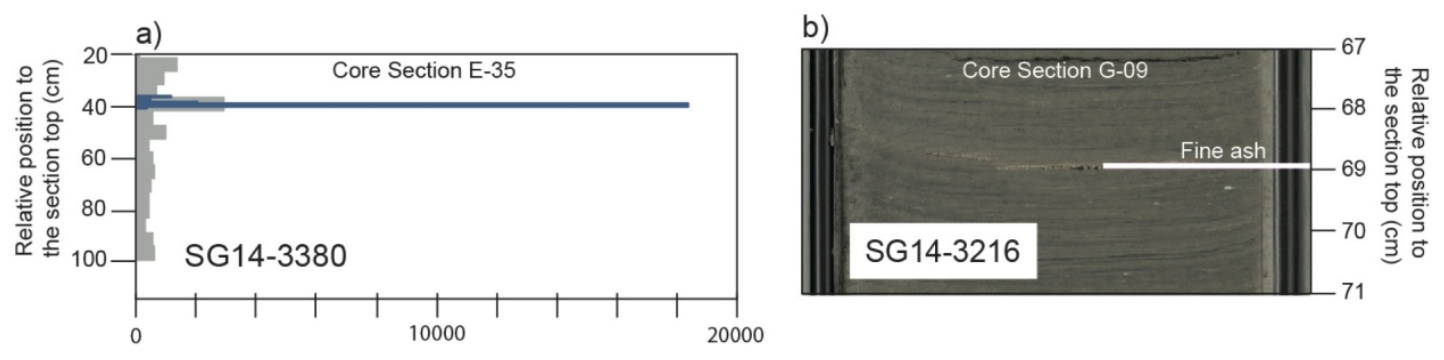

483 Figure 4. (a) Glass shard concentrations (shards per gram of dry sediment) preserved 484 in SG14 core E-35 and the positioning of cryptotephra SG14-3380. Concentration of 485 low-resolution $(5 \mathrm{~cm})$ samples are shown in grey and high-resolution samples $(1 \mathrm{~cm})$ 486 487 are overlain in blue. Shard counts for the other Holocene cryptotephra layers are published by McLean et al. (2018). (b) Photograph of visible tephra layer SG14-3216 in 488 Lake Suigetsu Core G-09. 
489 Two Holocene Changbaishan eruptions are preserved in the sediments: SG144901058 at 8,166 - 8,099 IntCal13 yrs BP (McLean et al., 2018); and SG06-0226, 491 which has been correlated to the AD 946 B-Tm tephra from the ME (McLean et 492 al., 2016; Hakozaki et al., 2017; Oppenheimer et al., 2017). Several other 493 widespread markers have been identified in the Holocene sediments, which are 494 able to stratigraphically separate eruption events from Ulleungdo and 495 Changbaishan (Figure 3; Table 1). SG14-1185 stratigraphically separates the 496 SG06-1288 and SG14-1091 Ulleungdo layers, and the K-Ah (7.3 ka; Kikai 497 volcano) and To-Cu (5.9 ka; Towada) tephra layers separate SG14-1091 and 498 SG14-0830 (McLean et al., 2018; Table 1; Figure 3).

499

500

4.2. Major and trace element volcanic glass geochemistry

501

502

4.2.1. Ulleungdo glass geochemistry

503

504 The newly analysed glass of SG14-3216 geochemically overlaps with the other 505 previously identified Ulleungdo derived tephra layers preserved in the Suigetsu 506 tephrostratigraphy (e.g., SG06-1288, SG14-1091 and SG14-0803). Collectively 507 they straddle the phonolitic/trachytic boundary on the basis of the Total Alkalis 508 versus Silica (TAS) classification (Le Bas et al., 1986) and contain $60-63$ wt. $509 \% \mathrm{SiO}_{2}$, ca. 7 wt. $\% \mathrm{~K}_{2} \mathrm{O}$ and $19-20$ wt. $\% \mathrm{Al}_{2} \mathrm{O}_{3}$ (Table 2; Figure 5). These 510 glasses are characterised by $<2.5 \mathrm{wt}$ \% $\mathrm{CaO}$ and contain between 2.5 and 3.5 511 wt. \% $\mathrm{FeO}^{\top}$. 
513 When normalised to the primitive mantle (Sun and McDonough, 1989), we find 514 the newly obtained trace element compositions of SG14-3216 and SG14-1091 515 show enrichments in the Light Rare Earth Elements (LREE) relative to the 516 Heavy Rare Earth Elements (HREE) (La/Yb $=30-35 \mathrm{ppm})$ and significant 517 depletions in $\mathrm{Ba}, \mathrm{Sr}$ and $\mathrm{Eu}$ that reflect $\mathrm{K}$-feldspar fractionation (Figure 6). The 518 paucity of a depletion in $\mathrm{Nb}$ and $\mathrm{Ta}$ content within these volcanic glasses, when 519 normalised to the primitive mantle, is inconsistent with subduction related 520 volcanism (Figure 6).

521

522 The four tephra layers with Ulleungdo compositions are difficult to distinguish 523 using their major element glass compositions, but we find that the younger 524 glasses of SG14-0803 are more elevated in $\mathrm{CaO}$ (by ca. 0.5 wt. \%), compared 525 to the early Holocene and SG14-3216 glass (Figure 5c). In addition, the alkaline 526 glasses of SG14-3216 (59.5- 62.5 wt. \% $\mathrm{SiO}_{2}$ and total alkalis $\left[\mathrm{Na}_{2} \mathrm{O}+\mathrm{K}_{2} \mathrm{O}\right]$ of 52711.6 - 14.9 wt. \%) can be discriminated from SG14-1091 by larger feldspar528 related depletions in $\mathrm{Sr}, \mathrm{Ba}$ and $\mathrm{Eu}$, that are normalised to primitive mantle 529 compositions (Figure 6). The alkaline glass shards of SG14-0433 $\left(\mathrm{Na}_{2} \mathrm{O}+\mathrm{K}_{2} \mathrm{O}\right.$ $530=10.4-11.0$ ) are also likely to derive from Ulleungdo, but contain ca. 2.5 wt. \% 531 lower $\mathrm{K}_{2} \mathrm{O}$, and ca. 2 wt. \% higher $\mathrm{CaO}$ compared to the older eruption events 532 outlined here (Figure 5a; 5c). 
533 Table 2. Average major, minor and trace element glass compositions of the Ulleungdo 534 and Changbaishan tephra layers in the Lake Suigetsu sediment core.

\begin{tabular}{|c|c|c|c|c|c|c|c|c|c|c|}
\hline \multirow{3}{*}{ wt. (\%) } & \multicolumn{2}{|c|}{ SG14-0433 } & \multicolumn{2}{|c|}{ SG14-0803 } & \multicolumn{2}{|c|}{ SG14-1091 } & \multicolumn{2}{|c|}{ SG06-1288 } & \multicolumn{2}{|c|}{ SG14-3216 } \\
\hline & \multicolumn{2}{|c|}{ McLean et al. 2018} & \multicolumn{2}{|c|}{ McLean et al. 2018} & \multicolumn{2}{|c|}{ McLean et al. 2018} & \multicolumn{2}{|c|}{ Smith et al. 2011} & \multicolumn{2}{|c|}{ this study } \\
\hline & Mean & $\pm 1 \sigma$ & Mean & $\pm 1 \sigma$ & Mean & $\pm 1 \sigma$ & Mean & $\pm 1 \sigma$ & Mean & $\pm 1 \sigma$ \\
\hline $\mathrm{SiO}_{2}$ & 61.76 & 0.16 & 60.54 & 0.63 & 60.52 & 0.24 & 60.85 & 0.42 & 60.75 & 0.67 \\
\hline $\mathrm{TiO}_{2}$ & 0.79 & 0.05 & 0.62 & 0.07 & 0.51 & 0.08 & 0.50 & 0.07 & 0.39 & 0.07 \\
\hline $\mathrm{Al}_{2} \mathrm{O}_{3}$ & 16.66 & 0.05 & 19.48 & 0.30 & 19.87 & 0.22 & 19.55 & 0.17 & 19.85 & 0.28 \\
\hline $\mathrm{FeO}^{\top}$ & 5.65 & 0.17 & 3.16 & 0.42 & 2.77 & 0.24 & 3.16 & 0.19 & 3.12 & 0.16 \\
\hline $\mathrm{MnO}$ & 0.23 & 0.05 & 0.14 & 0.10 & 0.15 & 0.03 & 0.14 & 0.05 & 0.18 & 0.05 \\
\hline $\mathrm{MgO}$ & 1.09 & 0.06 & 0.48 & 0.12 & 0.23 & 0.03 & 0.30 & 0.06 & 0.17 & 0.07 \\
\hline $\mathrm{CaO}$ & 6.07 & 0.18 & 6.60 & 0.60 & 6.95 & 0.40 & 1.61 & 0.17 & 1.34 & 0.12 \\
\hline $\mathrm{Na}_{2} \mathrm{O}$ & 2.57 & 0.08 & 1.99 & 0.33 & 1.48 & 0.14 & 6.51 & 0.79 & 7.28 & 0.96 \\
\hline $\mathrm{K}_{2} \mathrm{O}$ & 4.59 & 0.10 & 6.61 & 0.21 & 7.03 & 0.19 & 7.07 & 0.28 & 6.50 & 0.33 \\
\hline $\mathrm{P}_{2} \mathrm{O}_{5}$ & 0.36 & 0.04 & 0.17 & 0.05 & 0.05 & 0.04 & 0.10 & 0.03 & 0.05 & 0.03 \\
\hline $\mathrm{Cl}$ & 0.23 & 0.03 & 0.21 & 0.04 & 0.40 & 0.08 & 0.24 & 0.03 & 0.37 & 0.10 \\
\hline Analytical total & 96.85 & & 96.84 & & 97.81 & & 99.72 & & 97.03 & \\
\hline \multirow[t]{3}{*}{$n$} & \multicolumn{2}{|c|}{8} & \multicolumn{2}{|c|}{19} & \multicolumn{2}{|c|}{24} & \multicolumn{2}{|c|}{12} & \multicolumn{2}{|c|}{37} \\
\hline & \multicolumn{2}{|c|}{ SG06-0226 } & \multicolumn{2}{|c|}{ SG14-1058 } & \multicolumn{2}{|c|}{ SG14-3380 } & & & & \\
\hline & \multicolumn{2}{|c|}{ McLean et al. 2016} & \multicolumn{2}{|c|}{ McLean et al. 2018} & \multicolumn{2}{|c|}{ this study } & & & & \\
\hline wt. (\%) & Mean & $\pm 1 \sigma$ & Mean & $\pm 1 \sigma$ & Mean & $\pm 1 \sigma$ & & & & \\
\hline $\mathrm{SiO}_{2}$ & 74.89 & 0.21 & 75.01 & 0.18 & 66.26 & 0.70 & & & & \\
\hline $\mathrm{TiO}_{2}$ & 0.22 & 0.04 & 0.20 & 0.03 & 0.60 & 0.09 & & & & \\
\hline $\mathrm{Al}_{2} \mathrm{O}_{3}$ & 10.27 & 0.10 & 10.28 & 0.11 & 14.97 & 0.28 & & & & \\
\hline $\mathrm{FeO}^{\top}$ & 4.05 & 0.14 & 3.89 & 0.10 & 5.12 & 0.14 & & & & \\
\hline $\mathrm{MnO}$ & 0.08 & 0.05 & 0.07 & 0.03 & 0.15 & 0.04 & & & & \\
\hline $\mathrm{MgO}$ & 0.02 & 0.03 & 0.01 & 0.01 & 0.25 & 0.06 & & & & \\
\hline $\mathrm{CaO}$ & 0.22 & 0.02 & 5.30 & 0.16 & 1.24 & 0.17 & & & & \\
\hline $\mathrm{Na}_{2} \mathrm{O}$ & 5.36 & 0.15 & 0.20 & 0.02 & 5.67 & 0.66 & & & & \\
\hline $\mathrm{K}_{2} \mathrm{O}$ & 4.38 & 0.09 & 4.50 & 0.06 & 5.49 & 0.09 & & & & \\
\hline $\mathrm{P}_{2} \mathrm{O}_{5}$ & - & - & 0.01 & 0.01 & 0.09 & 0.03 & & & & \\
\hline $\mathrm{Cl}$ & 0.50 & 0.03 & 0.52 & 0.02 & 0.16 & 0.02 & & & & \\
\hline Analytical total & 96.19 & & 95.54 & & 95.90 & & & & & \\
\hline$n$ & 2 & & & & & & & & & \\
\hline
\end{tabular}

\begin{tabular}{|c|c|c|c|c|c|c|c|c|c|c|}
\hline \multirow[b]{3}{*}{ ppm } & \multicolumn{2}{|c|}{ SG06-0226 } & \multicolumn{2}{|c|}{ SG14-1058 } & \multicolumn{2}{|c|}{ SG14-1091 } & \multicolumn{2}{|c|}{ SG14-3216 } & \multicolumn{2}{|c|}{ SG14-3380 } \\
\hline & \multicolumn{2}{|c|}{ this study } & \multicolumn{2}{|c|}{ this study } & \multicolumn{2}{|c|}{ this study } & \multicolumn{2}{|c|}{ this study } & \multicolumn{2}{|c|}{ this study } \\
\hline & Mean & $\pm 1 \sigma$ & Mean & $\pm 1 \sigma$ & Mean & $\pm 1 \sigma$ & Mean & $\pm 1 \sigma$ & Mean & $\pm 1 \sigma$ \\
\hline $\mathrm{Rb}$ & 396.4 & 9.8 & 383.9 & 23.9 & 188.7 & 10.1 & 195.4 & 19.1 & 143.5 & 8.9 \\
\hline $\mathrm{Sr}$ & 2.2 & 0.6 & 4.4 & 0.9 & 59.5 & 36.2 & 14.3 & 10.2 & 25.0 & 24.4 \\
\hline Y & 143.3 & 3.9 & 149.8 & 11.4 & 23.5 & 2.0 & 26.0 & 2.9 & 51.1 & 3.9 \\
\hline $\mathrm{Zr}$ & 2415.2 & 80.0 & 2302.5 & 189.8 & 626.0 & 50.9 & 709.6 & 104.3 & 741.4 & 45.8 \\
\hline $\mathrm{Nb}$ & 286.1 & 8.9 & 261.1 & 21.1 & 169.8 & 11.5 & 175.2 & 21.2 & 97.0 & 5.5 \\
\hline $\mathrm{Ba}$ & 6.4 & 0.9 & 6.6 & 2.5 & 99.1 & 83.5 & 16.3 & 13.3 & 77.3 & 57.3 \\
\hline La & 138.9 & 4.5 & 125.2 & 14.6 & 86.4 & 4.3 & 98.2 & 9.0 & 76.4 & 4.7 \\
\hline $\mathrm{Ce}$ & 286.9 & 13.5 & 243.2 & 12.3 & 144.8 & 6.9 & 161.7 & 15.7 & 154.3 & 9.6 \\
\hline $\operatorname{Pr}$ & 31.9 & 1.2 & 28.3 & 1.8 & 12.8 & 0.9 & 14.5 & 1.2 & 17.1 & 1.1 \\
\hline $\mathrm{Nd}$ & 115.8 & 4.8 & 102.3 & 6.9 & 39.3 & 3.5 & 43.9 & 4.7 & 65.6 & 6.4 \\
\hline Sm & 27.6 & 1.2 & 26.1 & 4.5 & 5.6 & 1.0 & 6.4 & 0.7 & 12.9 & 1.9 \\
\hline Eu & 0.3 & 0.1 & 0.3 & 0.3 & 1.5 & 0.3 & 0.6 & 0.2 & 0.6 & 0.2 \\
\hline Gd & 26.7 & 1.5 & 28.0 & 3.3 & 5.0 & 1.4 & 5.4 & 1.9 & 10.7 & 1.4 \\
\hline Dy & 25.3 & 1.8 & 25.5 & 2.2 & 3.8 & 0.6 & 4.4 & 0.6 & 9.3 & 0.9 \\
\hline $\mathrm{Er}$ & 14.0 & 0.6 & 14.0 & 1.6 & 2.5 & 0.5 & 2.8 & 0.6 & 5.1 & 0.7 \\
\hline $\mathrm{Yb}$ & 11.4 & 0.5 & 11.2 & 2.0 & 2.6 & 0.4 & 3.1 & 0.7 & 4.3 & 0.6 \\
\hline $\mathrm{Hf}$ & 55.6 & 2.3 & 55.6 & 5.4 & 12.0 & 1.1 & 13.4 & 2.1 & 16.9 & 1.2 \\
\hline $\mathrm{Ta}$ & 17.0 & 1.1 & 16.4 & 1.9 & 9.8 & 0.7 & 9.7 & 1.1 & 5.6 & 0.5 \\
\hline Th & 49.9 & 3.1 & 49.6 & 5.0 & 23.5 & 1.9 & 25.2 & 3.2 & 14.1 & 1.1 \\
\hline U & 10.8 & 0.7 & 9.7 & 0.9 & 4.8 & 0.5 & 5.3 & 0.9 & 2.8 & 0.3 \\
\hline $\mathrm{Y} / \mathrm{Th}$ & 2.9 & 0.2 & 3.0 & 0.1 & 1.0 & 1.1 & 1.0 & 0.1 & 3.6 & 0.2 \\
\hline $\mathrm{Zr} / \mathrm{Th}$ & 48.5 & 2.5 & 46.5 & 2.0 & 26.6 & 27.5 & 28.1 & 2.3 & 52.6 & 3.3 \\
\hline $\mathrm{La} / \mathrm{Yb}$ & 12.1 & 0.4 & 11.3 & 1.4 & 34.4 & 6.5 & 32.7 & 4.9 & 18.0 & 2.4 \\
\hline$n$ & 8 & & 5 & & 13 & & 8 & & 10 & \\
\hline
\end{tabular}

$535\left(\mathrm{FeO}^{\top}=\right.$ all Fe reported as $\left.\mathrm{FeO}\right)$. Raw dataset and secondary standards are included in the Supplementary Material. 

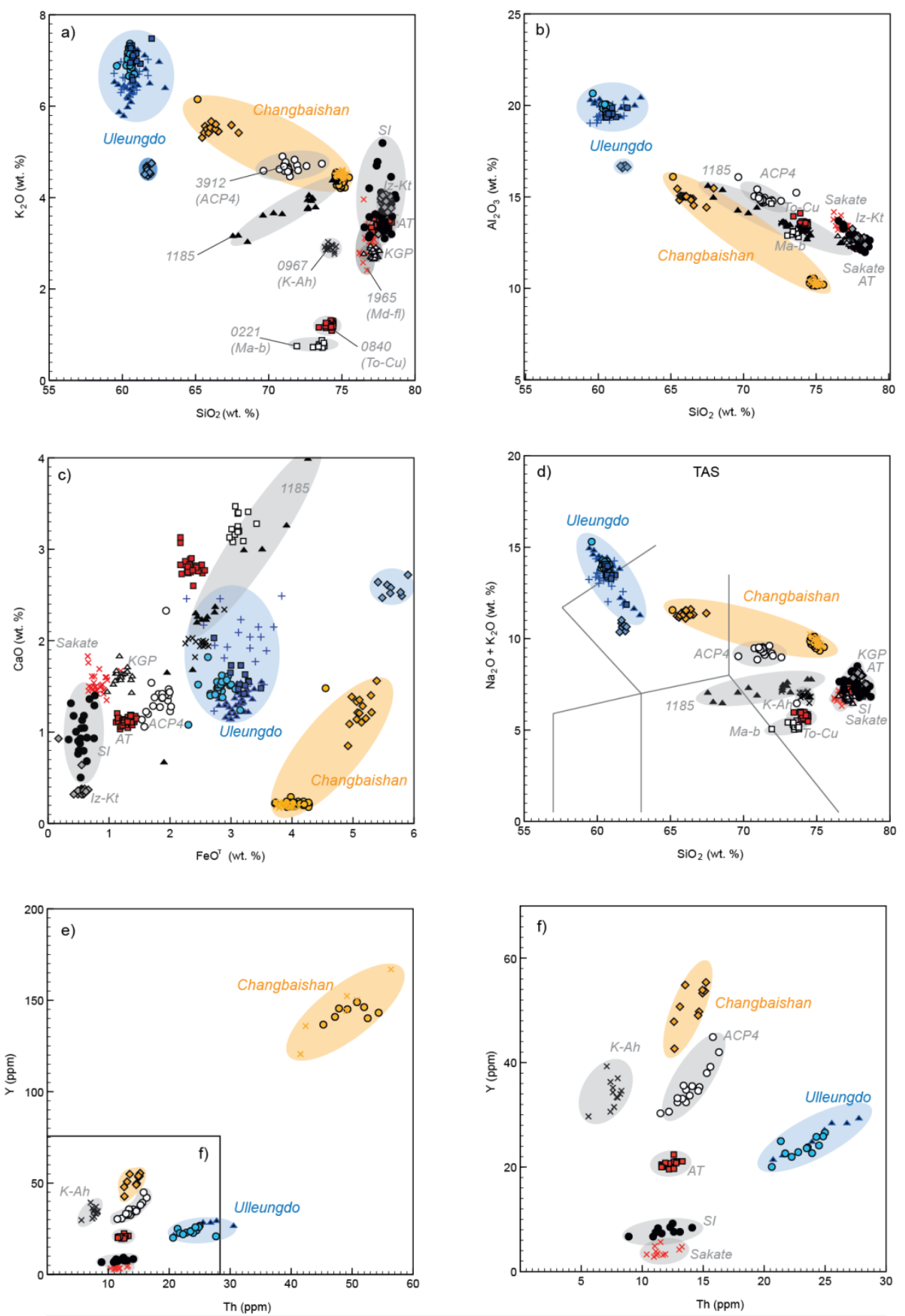

538 Figure 5. Glass shard major $(5 a-d)$ and trace $(5 e-f)$ element compositions of 539 Ulleungdo (South Korea; shown in blue), Changbaishan (North Korea/China; shown in 540 orange), and key Japanese tephra layers that are preserved in the Lake Suigetsu 541 sediments (shown in grey and black) (Smith et al., 2013; McLean et al., 2016, 2018; 542 Albert et al., 2018, 2019). (d) Total alkali versus silica plot (TAS) with whole-rock 543 classification based on Le Bas et al., 1986). 


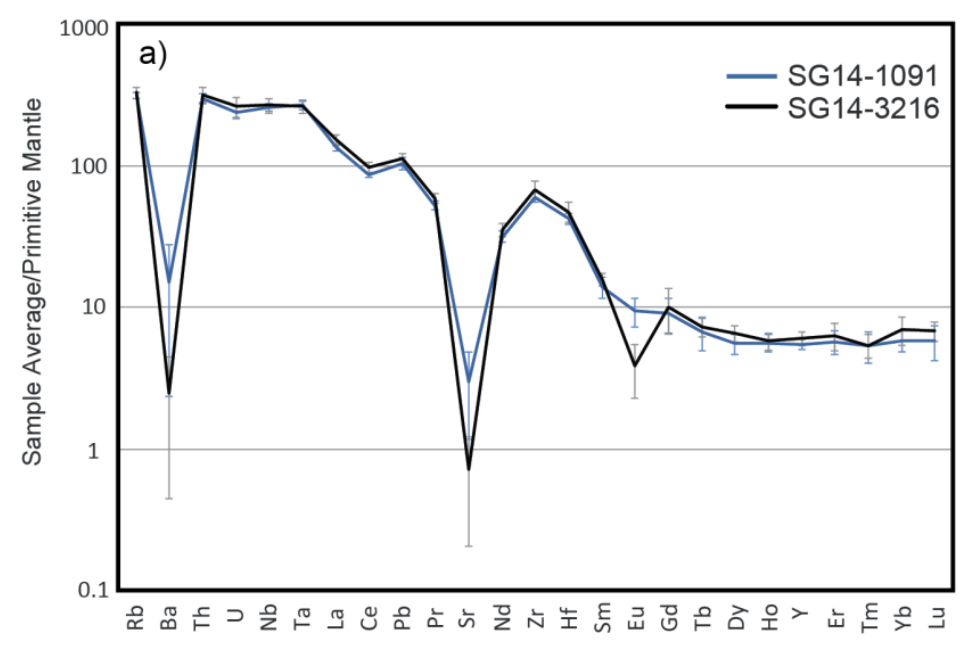

545 Figure 6. Primitive mantle normalised trace element compositions of glasses of: (a) 546 Ulleungdo tephra layers (SG14-1091 and SG14-3216) in the Lake Suigetsu sequence; 547 (b) Changbaishan tephra layers (SG06-0225, SG14-1058 and SG14-3380) in 548 comparison to proximal ME rhyolitic (C2 - C3) and trachytic (C1) proximal deposits 549 (Chen et al., 2016). Primitive mantle values follow Sun and McDonough (1989).

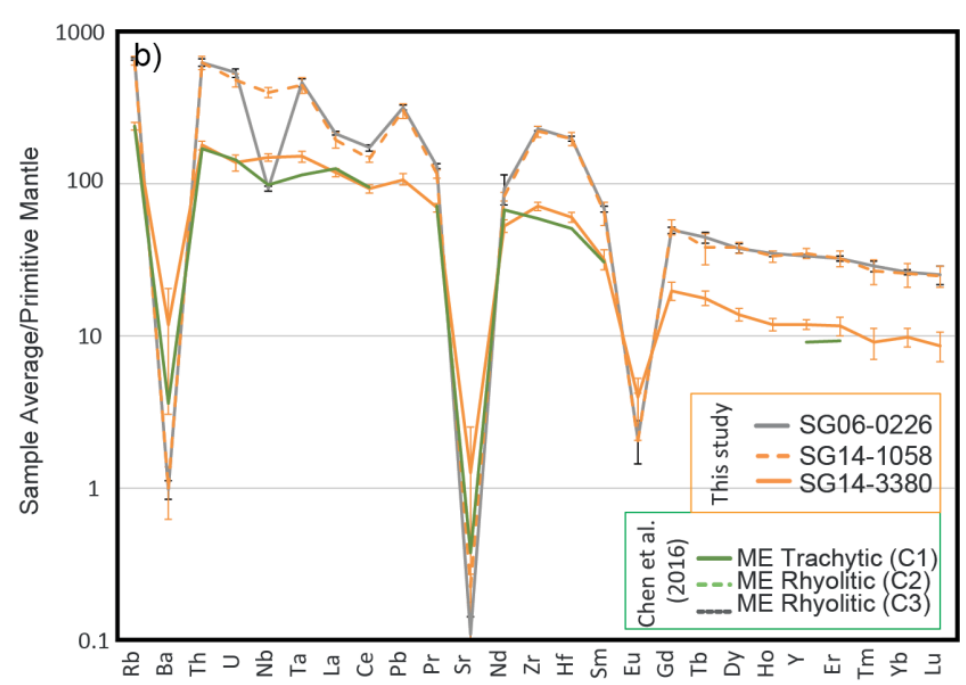

\section{2}

\subsubsection{Changbaishan glass geochemistry}

553 The three Changbaishan derived tephra layers (e.g., SG14-3380, SG14-1058 554 and SG06-0226) contain both rhyolitic and trachytic glass compositions $\left(\mathrm{Na}_{2} \mathrm{O}+\right.$ $555 \mathrm{~K}_{2} \mathrm{O}=>9.5$ wt. \%; Le Bas et al., 1986), with $\mathrm{SiO}_{2}$ ranging from 65.5 to 75.5 wt. $556 \%$ (Table 2; Figure 5d). They contain < 1.6 wt. \% CaO, and between 3.7 and 5.4 557 wt. \% $\mathrm{FeO}^{\top}$ (Figure 5c). New trace element analyses indicate that when 
558 normalised to primitive mantle compositions, all glasses are enriched in LREE

559 relative to $\mathrm{HREE}$, with $\mathrm{La} / \mathrm{Yb}$ ratios higher in those of SG14-3880, relative to

560 SG14-1058 and SG06-0226 (Table 2) and show pronounced negative feldspar-

561 related anomalies in $\mathrm{Ba}, \mathrm{Sr}$ and $\mathrm{Eu}$ (Figure 6).

562

563 The newly analysed glasses of SG14-3380 are exclusively trachytic (65.4 56467.9 wt. $\% \mathrm{SiO}_{2}, 14.4-15.5$ wt. $\% \mathrm{Al}_{2} \mathrm{O}_{3}$, and $\mathrm{Na}_{2} \mathrm{O}+\mathrm{K}_{2} \mathrm{O}=8.7-11.7$ wt. \%) and are compositionally similar to the single trachytic analysis from SG06-0226.

Trace element compositions for SG14-3380 are homogenous with $14.1 \pm 1.1$

567 ppm Th, $144 \pm 9.0$ ppm Rb, and $51 \pm 4$ ppm Y (Table 2). Unfortunately, no trace 568 elements could be obtained for the trachytic end-member of SG06-0226 for 569 further comparison with SG14-3380.

570

571 As discussed by McLean et al. (2018), the rhyolitic SG06-0226 glass 572 compositions overlap with SG14-1058 for all major elements (Table 2; Figure 573 5). Both tephras contain glass compositions that are geochemically 574 homogenous, with ca. 75 wt. $\% \mathrm{SiO}_{2}, 10.3$ wt. $\% \mathrm{Al}_{2} \mathrm{O}_{3}$ and ca. 4.4 wt. $\% \mathrm{~K}_{2} \mathrm{O}$, 575 and are characterised by very low $\mathrm{CaO}$ concentrations (< $0.3 \mathrm{wt} . \%)$. The newly 576 generated trace element compositions of SG14-0226 and SG06-1058 show 577 significant overlap, and are more enriched in incompatible elements (e.g., Th, 578 Ta and $\mathrm{Y}$ ), whilst depleted in compatible elements (e.g., Sr, Ba, and Eu) relative 579 to the trachytic glass of SG14-3380 (Table 2; Figure 6b). SG06-0226 and 580 SG14-1058 have similar mantle normalised profiles and levels of incompatible 581 trace element enrichment (Figure 6). Glasses of both tephra layers have greater 582 feldspar-related depletions in $\mathrm{Ba}, \mathrm{Sr}$ and Eu relative to SG14-3380. The SG065830226 glasses show a significant depletion in $\mathrm{Nb}$, which is not observed in 
584 SG14-1058 and SG14-3380, which given the intraplate setting of the volcano 585 may relate to late stage, high-level fractionation processes.

586

587

\section{5. Review of Ulleungdo and Changbaishan eruption framework}

589

590 Here, the distal ash deposits erupted from Ulleungdo and Changbaishan are 591 outlined and reviewed using the relative stratigraphy, geochemical glass 592 compositions and eruption chronology. Published occurrences are centred on 593 the Lake Suigetsu tephrostratigraphy to provide an integrated framework that is 594 constrained by numerous widespread ash layers erupted from Japanese 595 volcanoes (Figure 7). There are no pre-50 ka visible ash layers in Lake 596 Suigetsu with Ulleungdo or Changbaishan compositions, but we should 597 highlight that cryptotephra extraction techniques have not yet been carried out 598 on these older sediments. It is possible that there are other pre-50 ka Ulleungdo 599 or Changbaishan layers preserved cryptically in Lake Suigetsu. 
600 Figure 7. Summary tephrostratigraphy of proximal and distal archives that contain ash 601 erupted from Ulleungdo (blue boxes) and Changbaishan (orange boxes) (see Figure 1 602 for archive location). Widespread Japanese tephra layers, which provide valuable 603 chronostratigraphic markers, are also shown in grey boxes. Alkali-rich ashes erupted 604 from Ulleungdo and Changbaishan are routinely identified in marine cores extracted 605 from the Sea of Japan (East Sea) and high resolution lake archives in Japan. $1=$ Chun 606 et al. (1997); 2 = Lim et al. (2013); 3 = Chun et al. (2007); 4 = Arai et al. (1981); $5=$ 607 Nakajima et al. (1996); 6 = Ikehara et al. (2004); $7=$ Derkachev et al. (in press); $8=$ 608 Ikehara (2003); 9 = Sawada et al. (1997); $10=$ Higashino et al. (2005); $11=$ Nagahashi 609 et al. (2004); 12 = Smith et al. (2011; 2013), Albert et al. (2018; 2019), McLean et al. 610 (2016; 2018; this study). Due to the paucity of glass data from pre-Holocene eruptions 611 of Ulleungdo and Changbaishan, these units cannot be correlated to distal ash 612 deposits elsewhere. 
614

615 Ulleungdo has erupted explosively at least five times over the last 86 kyrs (since 616 the eruption of the Aso-4 tephra) with associated widespread ash fall events 617 recognised by the ca. 60 - 61 ka U-Sado tephra (Lim et al., 2013); the ca. 40.1 618 ka U-Ym tephra (this study); the ca. 10 ka U-Oki/U-4 tephra (Smith et al., 2011; 619 2013); ca. 8.4 ka U-3 tephra (McLean et al., 2018); and the ca. 5.7 ka U-2 620 tephra (McLean et al., 2018). The known distal deposits of these events and 621 possible proximal correlations are illustrated in Figure 7 and discussed further 622 below.

623

624 5.1.1. Post 86 ka (Aso-4) Ulleungdo eruptions

625

626 Distal ash layers erupted from Ulleungdo were identified stratigraphically below 627 the AT tephra (30 ka) in marine sediments obtained from the Oki ridge (Arai et 628 al., 1981) and Yamato Basin (Ikehara et al., 2004). These pre-AT Ulleungdo 629 tephra layers were originally considered to be from a single eruption, but the 630 age was controversial. However, Chun et al. (2007) clarified the issue by 631 identifying two separate alkaline ash deposits in marine core MD01-2407 632 (Figure 1), which they named SKPI and SKPII, and were dated to $40-41 \mathrm{ka}$ 633 and 60 - $61 \mathrm{ka}$, respectively, based on correlations with the regional-scale 634 thinly-laminated marine stratigraphy (Tada, 1999; Chun et al., 2007). 635 

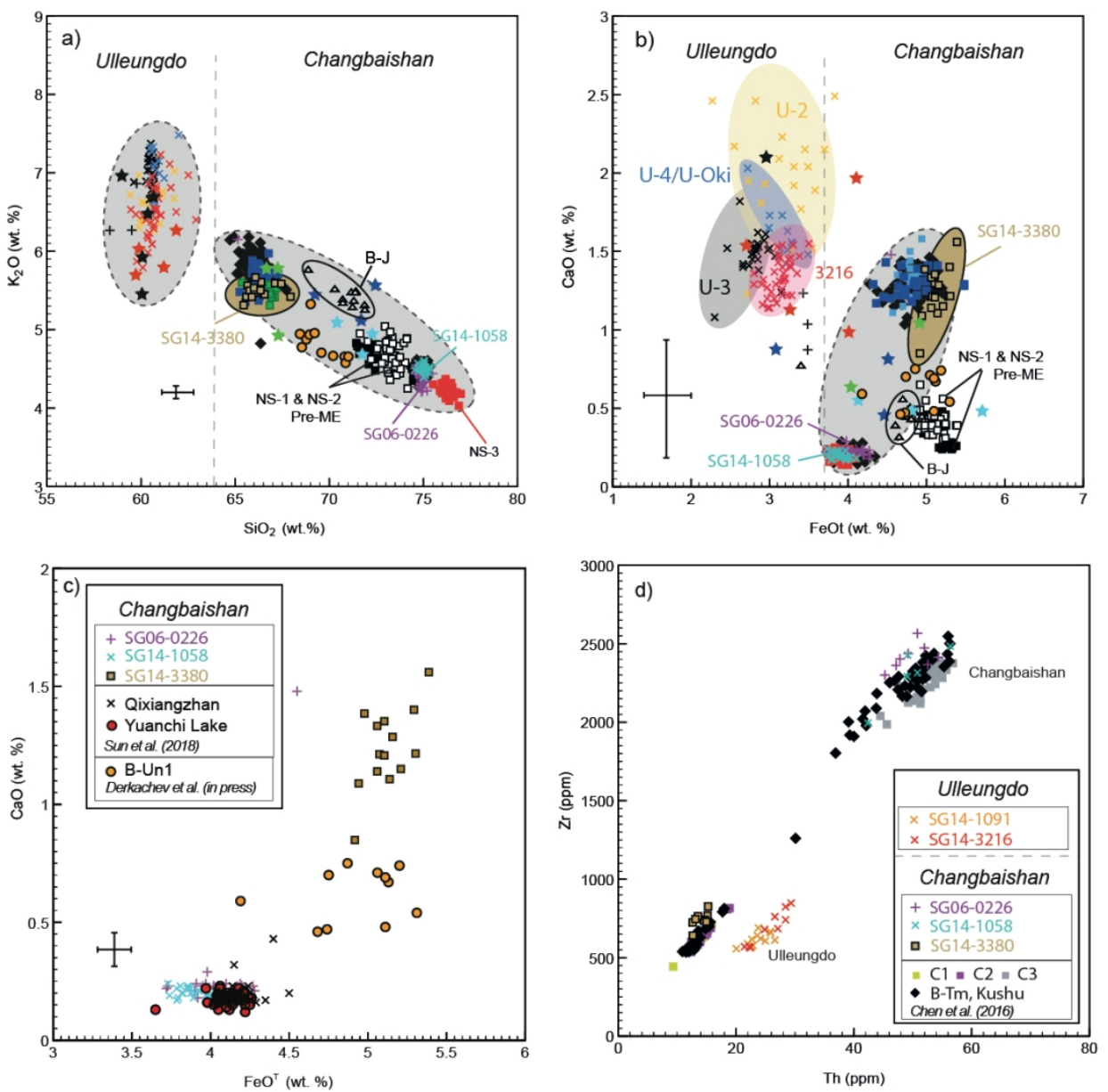

637 Figure 8. Glass shard major and trace element compositions of Ulleungdo (SG14638 0803; SG14-1091; SG06-1288; SG14-3216) and Changbaishan (SG06-0226; SG14639 1058; SG14-3380) tephra layers preserved in the Lake Suigetsu archive, compared to 640 other proximal (Chen et al., 2016; Sun et al., 2017, 2018) and distal occurrences 641 (Ikehara et al., 2004; Lim et al., 2013; Derkachev et al. (in press). Error bars represent $6422 \times$ standard deviations of repeat analysis of the StHs6/80-G MPI-DING reference 643 glass analyses, error bars for (d) are smaller than the data symbols. 
645 Lim et al. (2013) also identified two equivalent cryptotephra layers in several 646 other marine cores northeast of Ulleungdo (e.g., GH86-2-N, GH89-2-25, GH89647 2-26 and GH89-2-28), which were stratigraphically positioned between the 648 rhyolitic Aso-4 and AT tephra. These distal tephra layers were therein named 649 the Ulleung-Yamato (U-Ym) and Ulleung-Sado-Oki (U-Sado), and are 650 considered to be equivalent to SKP-I and SKP-II, respectively (Figure 7).

651

652 The Lake Suigetsu sediments verify that an ash fall event from Ulleungdo 653 occurred at 40,332 - 39,816 IntCal13 yrs BP (95.4\% confidence interval). This $6541 \mathrm{~mm}$ thick ash layer (SG14-3216; Figure 4) contains volcanic glass that 655 compositionally overlaps the other Ulleungdo-derived tephra deposits preserved 656 in the Suigetsu sequence (e.g. SG06-1288, SG14-1091), and other distal and 657 proximal occurrences of the U-Oki tephra (Figure 5; Figure 8; Furuta et al., 658 1986; Nagahashi et al., 2004; Chun et al., 2007; Park et al., 2003, 2007). 659

660 Although grain-specific glass compositional datasets for the U-Ym tephra 661 preserved in the Sea of Japan have not been published for comparison, the 662 broad geochemical and chronological data and the stratigraphic position is 663 consistent with SG14-3216, meaning this ash must also correlate to the same 664 eruption of Ulleungdo. The Suigetsu-derived deposit age of 40,332 - 39,816 665 IntCal13 yrs BP (95.4\% confidence interval) provides the most precise eruption 666 age, and this date can now be imported into other site-specific age models that 667 contain this marker.

668 
669 No other distal ash occurrences have been reported that are chronologically or 670 geochemically consistent with the ca. 19 ka eruption (proximal unit N-5; Kim et 671 al., 2014), suggesting that this eruption of Ulleungdo was probably not 672 widespread.

673

\section{5.1.2. Holocene Ulleungdo eruptions}

675

676 As previously outlined, the largest known Plinian eruption from Ulleungdo 677 generated the U-Oki tephra layer that is dated to $10,230-10,171$ IntCal13 yrs 678 BP (95.4 \% confidence interval; Smith et al., 2011, 2013). The U-Oki ash is 679 found in several high-resolution sedimentary records in Japan, including Lake 680 Biwa (BT-4; Nagahashi et al., 2004) and Lake Suigetsu (SG06-1288; Smith et 681 al., 2011) (Figure 7). This U-Oki tephra is the only distal tephra that has been 682 correlated to proximal deposits on Ulleungdo, and equates to the proximal U-4 683 unit of Shiihara et al. (2011).

684

685 Lake Suigetsu tephra layers SG14-1091 (ca. 8.4 ka) and SG14-0803 (ca. 5.7 686 ka) overlay the U-Oki tephra and are considered distal equivalents of proximal 687 deposits U-3 and U-2, respectively, due to their close agreement to the proximal 688 radiocarbon dates of soils between fall units (Okuno et al., 2010). Furthermore, 689 the K-Ah tephra is stratigraphically positioned between the U-3 (SG14-1091) 690 and U-2 (SG14-0803) deposits (Shiihara et al., 2011). Distal equivalents of the 691 U-3 eruption have been reported in the Sea of Japan (TRG1 sediment core; 692 Domitsu et al., 2002), Lake Biwa (Nagahashi et al., 2004), and close to 693 Hakusan volcano in central Honshu (Higashino et al., 2005). In comparison, 
694 SG14-0803 is the only known distal equivalent of the U-2 tephra, indicating that

695 it was either a lower magnitude event or the eruption plume was dispersed in a 696 different direction.

697

698 The proximal deposits of the youngest U-1 eruption of Ulleungdo suggest it was 699 a small strombolian-type eruption with a lava dome extrusion (Kim et al., 2014).

700 Whole rock trace element data reported for this youngest event have a distinct 701 tephriphonolite composition (Brenna et al., 2014). Similarly, distal SG14-0433

702 glass compositions are distinct from those of other Ulleungdo derived tephras in 703 Suigetsu. Unfortunately, the lack of proximal glass chemistry for the U-1 unit 704 means that this correlation cannot be confirmed but it is likely that the SG147050433 layer at 2,737 - 2,620 IntCal13 yrs BP (95.4 \% confidence interval) 706 correlates to the U-1 eruption.

\subsection{Changbaishan eruption history}

709

710 The newly identified Changbaishan-derived tephra layer outlined here, in 711 addition to the previously recognised layers, indicate that at least eight explosive eruptions have produced widespread ash dispersals over the last 86 713 kyrs. These include the: ca. 85.8 ka B-Ym tephra (Lim et al., 2013); ca. 67.6 ka 714 B-Sado tephra (Lim et al., 2013); ca. 50.5 ka B-J tephra (Ikehara et al., 2014; 715 Lim et al., 2013); ca. 42.5 ka B-Sg-42 tephra (this study), ca. 38 ka B-Un1 716 tephra (Derkachev et al., in press), ca. 25 ka B-V tephra (Machida and Arai, 717 2003); ca. 8.1 ka B-Sg-08 tephra (McLean et al., 2018); and AD 946 B-Tm 718 tephra associated with the ME (McLean et al., 2016; Hakozaki et al., 2017; 
719 Oppenheimer et al., 2017). All the known distal ash deposits associated with

720 eruptions at Changbaishan and possible correlations to proximal units on the

721 volcano are summarised in Figure 7 and are discussed below.

722

723 5.2.1. Post 86 ka (Aso-4) Changbaishan eruptions

724

725 To date, at least four individual tephra layers originating from Changbaishan

726 have been recognised in marine cores stratigraphically positioned between the

727 Aso-4 and AT tephra layers (Figure 7). The two oldest, Baegdusan-Yamato 728 Basin (B-Ym; ca. $85.8 \mathrm{ka}$ ) and Baegdusan-Sado-Oki (B-Sado; ca. $67.6 \mathrm{ka}$ ) 729 tephras, have been identified as cryptotephra horizons in both the GH89-2-26 730 and GH89-2-28 marine cores (Figure 7; Lim et al., 2013). Lim et al. (2013) 731 report that the B-Ym and B-Sado glass shards are trachytic in composition 732 (Figure 8). More recently, Derkachev et al. (in press) also identify visible 733 deposits in several marine cores across the Yamato and Pervenets Rise (e.g., 734 cores Lv53-25, Lv53-20, Lv53-27, and Lv53-29) that they correlate to the B735 Sado tephra. The constructed age models for these marine cores suggest an 736 eruption age ca. $71 \mathrm{ka}$ (Derkachev et al., in press).

738 The Baegdusan-Japan (B-J) tephra is found between Ulleungdo U-Ym and U739 Sado tephra layers (Figure 7), and estimated to have been erupted at ca. 50 ka 740 based on correlations with the regional-scale thinly laminated layer 741 stratigraphy (Ikehara et al., 2004; Lim et al., 2013; Derkachev et al., in press).

742 Ikehara et al. (2004) and Lim et al. (2013) report a homogenous rhyolitic 743 composition for the B-J tephra, with ca. 71.2 wt. \% $\mathrm{SiO}_{2}$, ca. 12.0 wt. $\% \mathrm{Al}_{2} \mathrm{O}_{3}$, 
744 and total alkalis of 11.1 wt. \% (Figure 8). It contrasts with the exclusively

745 trachytic glass compositions of the older ca. $67.6 \mathrm{ka}$ B-Sado tephra (Lim et al., 746 2013).

748 Derkachev et al. (in press) report a $5 \mathrm{~mm}$ thick volcanic ash layer in a sequence 749 (Lv53-23 at $211 \mathrm{~cm}$ ) from the Yamato Rise, about $270 \mathrm{~km}$ SE of Changbaishan, 750 in the Sea of Japan. This deposit is therein named the Baegdusan-Unknown (B-

751 Un1) tephra and represents another explosive event dated to around $38.3 \mathrm{ka}$.

752 The glass chemistry of this layer is somewhat distinct, containing ca. 73.9 wt. 753 $\%$, ca. 13.5 wt. $\% \mathrm{Al}_{2} \mathrm{O}_{3}$, and total alkalis of 8.2 wt. \%

754

755 The Lake Suigetsu sediments also provide evidence of another explosive 756 assigned to the late phase of the ME (e.g., NS-4 and NS-5 proximal deposits; Sun et al., 2017) (Figure 8) and other distal occurrences of the trachytic end 763 member of the B-Tm ash (e.g., Okuno et al., 2011; Hughes et al., 2013; Sun et 764 al., 2015; Chen et al., 2016). SG14-3380 does not geochemically overlap with 765 the reported composition of the ca. 38 ka B-Un1 tephra reported in the Yamato 766 Rise (Derkachev et al., in press), or the ca. 50.5 ka B-J tephra (Ikehara et al., 767 2004; Lim et al., 2013) clearly indicating that they represent separate eruptions 768 of Changbaishan. Here, we name the Suigetsu distal ash of this Changbaishan 
769 eruption (ca. 42 ka) as the Baegdusan-Suigetsu-42 (B-Sg-42) tephra, following

770 the convention of naming proximally undefined distal deposits using the type771 locality.

772

773 A post-AT distal tephra named the Baegdusan-Vladivostok (B-V) ash was found 774 in the Primorye regions of Russia, and in the north-eastern part of the Japan 775 Sea (Figure 1; Machida and Arai, 2003; Ikehara, 2003; Derkachev et al., in press). The eruption age is estimated to ca. 29 ka (Derkachev et al., in press).

\subsubsection{Holocene Changbaishan eruptions}

779

780 An eruption from Changbaishan was identified in Lake Suigetsu (SG14-1058) at

8,166 - 8,099 IntCal13 yrs BP (95.4 \% confidence interval; McLean et al., 2018)

783 and was the first known discovery of a large early Holocene eruption from this

784 Lake Yuanchi, located ca. $30 \mathrm{~km}$ east of Changbaishan in China, which is dated 785 to a similar age as the Suigetsu layer, 8,831 - 8,100 IntCal13 yrs BP $(95.4 \%$ 786 confidence interval; Sun et al., 2018). The major element glass compositions of

787 this Yuanchi tephra broadly overlap with those of SG14-1058 (Figure 8c), 788 although some offsets, which are close to instrumental/analytical uncertainty, 789 are observed. Sun et al. (2018) also suggest the Suigetsu SG14-1058 and 790 Yuanchi tephra are distal deposits from the eruption that produced the 791 Qixiangzhan comendite lava flow, but it is not known if there was an explosive 792 phase associated with this eruption, and the stratigraphic relationship between 793 the Qixiangzhan comendite and the explosive pre-ME fall deposits is not 
794 known. Furthermore, the chronological uncertainty on ${ }^{40} \mathrm{Ar} /{ }^{39} \mathrm{Ar}$ ages for the 795 Qixiangzhan comendite mean that it could be a separate eruption (e.g., Singer 796 et al., 2014; Yang et al., 2014). When normalised to mantle concentrations, we 797 find that SG14-1058 only shows a minor depletion in Nb, unlike SG06-0226 (B798 Tm ash) and C-3 unit (Chen et al., 2016), which could help identify the proximal 799 deposit. We suggest that the distal ash erupted from Changbaishan at ca. 8.1 800 ka (e.g., SG14-1508) is named Baegdusan-Suigetsu-08 (B-Sg-08). 801

802 No distal ash deposits have been identified that geochemically or 803 chronologically overlap with the pre-ME proximal deposits of NS-4 and NS-5 804 that are dated to ca. 4 - 5 ka (Sun et al., 2017). Similarly, even in the high805 resolution archives in northern Japan (e.g., Lake Kushu; Chen et al., 2019) 806 there are no clear isochrons representing post-ME ash eruptions of 807 Changbaishan.

808

809 6. Conclusions

810

811 Distal records can provide useful information on past eruption activity from 812 volcanoes whose deposits are inaccessible for various reasons, e.g., burial or 813 deposition into dynamic ocean environments. The new occurrences reported 814 here and considered with other known distal alkali-rich ash units found in 815 marine and lacustrine cores (spanning the last 86 kyrs) in the East Asian/Pacific 816 region provide an improved eruption framework for intraplate volcanoes, 817 Ulleungdo and Changbaishan. This framework shows that there are numerous 
818 explosive eruptions responsible for distal ash fall events that are only cryptically

819 recorded in the geological record.

820

821 Ulleungdo has erupted explosively at least five times over the last 86 kyrs (since

822 the deposition of the Aso-4 tephra) and these are: the $60-61 \mathrm{ka}$ U-Sado 823 tephra (Lim et al., 2013); the ca. $40.1 \mathrm{ka} \mathrm{U-Ym} \mathrm{tephra} \mathrm{(this} \mathrm{study);} \mathrm{the} \mathrm{ca.} 10 \mathrm{ka}$ 824 U-Oki/U-4 tephra (Smith et al., 2011; 2013); ca. 8.4 ka tephra (U-3; McLean et 825 al., 2018); and the ca. 5.7 ka U-2 tephra (McLean et al., 2018). Furthermore, it 826 is likely that a younger eruption from Ulleungdo occurred ca. $2.7 \mathrm{ka}$, but 827 chemical analyses of proximal deposits are required to confirm the correlation. 828 This age would be consistent with an eruption repose interval of $<3$ ka 829 throughout the Holocene.

830

831 The new Changbaishan-derived tephra layers identified in the Suigetsu 832 sediments indicate that at least eight explosive eruptions have produced 833 significant ash dispersals over the last 86 kyrs which include the: ca. 85.8 ka B834 Ym (Lim et al., 2013); ca. 70 ka B-Sado (Lim et al., 2013; Derkachev et al., in 835 press); ca. 50.5 ka B-J tephra (Ikehara et al., 2014; Lim et al., 2013; Derkachev 836 et al., in press); ca. 42.5 ka B-Sg-42 (this study), ca. 38 ka B-Un1 (Derkachev et 837 al., in press), ca. 25 ka B-V (Machida and Arai, 2003); ca. 8.1 ka B-Sg-08 838 (McLean et al., 2018); and AD 946 B-Tm tephra associated with the ME 839 (Hakozaki et al., 2017; Oppenheimer et al., 2017). It is possible that additional 840 ash fall events will be discovered in other distal records in the future, as there 841 are some proximal units near Changbaishan (e.g., the compositionally distinct 
842 NS-4 and NS-5 layers; Sun et al., 2017) that have not yet been correlated to 843 distal markers.

844

845 Even though Lake Suigetsu is located ca. $500 \mathrm{~km} \mathrm{E}$ of Ulleungdo and ca. 1000 $846 \mathrm{~km}$ SSE of Changbaishan (i.e., not downwind of the current prevailing winds), 847 tephra from these volcanoes is clearly preserved in the sediments. The 848 eruptions responsible for the $\mathrm{B}-\mathrm{Sg}-42$ and $\mathrm{B}-\mathrm{Sg}-08$ distal tephra must have 849 been large eruption events (i.e., greater than VEI 5-6), based on the shard 850 concentrations preserved in Suigetsu $(>18,000$ shards per gram of dried 851 sediment). Unfortunately, it is not possible to get better constraints on volume 852 and magnitude of these events given that they have not yet been found as 853 visible layers and have not been identified in multiple locations. The precise 854 ages provided in this paper from the Lake Suigetsu chronology may help locate 855 these deposits in other records, which may provide more information about the 856 eruptions and the dispersal of the events. Critically, these tephra occurrences 857 demonstrate that both Ulleungdo and Changbaishan have been more active 858 than previously thought, and the ash plumes from these explosive eruptions 859 were widespread.

860

861

\section{Acknowledgements}

863 The SG14 (formally 'Fukui-SG14') sediment coring campaign was funded by the 864 Fukui Prefectural government, and the coring was conducted by the team of 865 Seibushisui Co. Ltd. Japan, led by Mr. Atsumi Kitamura. KAKENHI grants by 866 MEXT, Japan (15H021443 and $18 \mathrm{H} 03744$ to $\mathrm{TN})$ as well as grants by Casio 
867 Science Promotion Foundation were used to purchase laboratory equipment 868 and consumables during the project. Trace element analysis was funded by the 869 Japan Society for the Promotion of Science (JSPS) 2018 Summer Program. DM 870 was funded by NERC (grant: NE/L002612/1) and part of the Environmental 871 Research Doctoral Training Program at the University of Oxford. PGA and RAS 872 were supported by Early Career Fellowships from the Leverhulme Trust (grant: 873 ECF-2014-438 and ECF-2015-396). Geochemical bi-plots were generated 874 using the RESET plot function (https://c14.arch.ox.ac.uk). We would like to 875 thank the two anonymous reviewers for their feedback on an earlier version of 876 the manuscript.

877

\section{References}

879

880 Albert, P. G., Tomlinson, E. L., Smith, V. C., Di Roberto, A., Todman, A., Rosi, 881 M., Marani, M., Muller, W. and Menzies, M. A. 2012. Marine-continental tephra 882 correlations: volcanic glass geochemistry from the Marsili Basin and the Aeolian 883 Islands, Southern Tyrrhenian Sea, Italy. Journal of Volcanology and 884 Geothermal Research, 229: 74-94 885

886 Albert, P. G., Tomlinson, E. L., Lane, C. S., Wulf, S., Smith, V. C., Coltelli, M., 887 Keller, J., Castro, D. L., Manning, C. J., Müller, W. and Menzies, M. A. 2013. 888 Late glacial explosive activity on Mount Etna: Implications for proximal-distal 889 tephra correlations and the synchronisation of Mediterranean archives. Journal 890 of Volcanology and Geothermal Research, 265: 9-26 891

892 Albert, P. G., Smith, V. C., Suzuki, T., Tomlinson, E., Nakagawa, T., Yamada, 893 K., McLean, D., Staff, R. A., Schlolaut, G., Takemura, K., Nagahashi, Y., 894 Kimura, I-P, SG06 Project Members. 2018. Constraints on the frequency and 895 dispersal of explosive eruptions at Sambe and Daisen volcanoes (South-West 
896 Japan Arc) from the distal Lake Suigetsu record (SG06 core). Earth-Science

897 Reviews, 185: 1004-1028

898

899 Albert, P. G., Smith, V. C., Suzuki, T., McLean, D., Tomlinson, E. L., Miyabuchi, 900 Y., Kitaba, I., Mark, D. F., Moriwaki, H., SG06 Project Members, Nakagawa, T.

901 2019. Geochemical characterisation of the widespread Japanese

902 tephrostratigraphic markers and correlations to the Lake Suigetsu sedimentary

903 archive (SG06 core). Quaternary Geochronology, 52: 103 - 131

904

905 Arai, F., Oba, T., Kitazato, H., Horibe, Y., Machida, H. 1981. Late Quaternary

906 tephrochronology and paleo-oceanography of the sediments of the Japan Sea.

907 Quaternary Research (Daiyonki-kenkyu) 20: 209-230 (in Japanese, with

908 English Abstract)

909

910 Blockley, S. P. E., Pyne-O’Donnell, S. D. F., Lowe, J. J., Matthews, I. P., Stone, 911 A., Pollard, A. M., Turney, C. S. M. and Molyneux, E. G. 2005. A new and less 912 destructive laboratory procedure for the physical separation of distal glass 913 tephra shards from sediments. Quaternary Science Reviews, 24: 1952-1960 914

915 Brenna, M., Price, R., Cronin, S. J., Smith, I. E., Sohn, Y. K., Kim, G. B. and 916 Maas, R. 2014. Final magma storage depth modulation of explosivity and 917 trachyte-phonolite genesis at an intraplate volcano: a case study from Ulleung 918 Island, South Korea. Journal of Petrology, 55: 709-747 919

920 Bronk Ramsey, C. 2008. Deposition models for chronological records.

921 Quaternary Science Reviews, 27: 42-60

922

923 Bronk Ramsey, C. 2017 OxCal Project, Version 4.3. Retrieved December 2017. 924 https://c14.arch.ox.ac.uk/oxcal/OxCal.html Retrieved June 2017

925

926 Bronk Ramsey, C., Staff, R. A., Bryant, C. L., Brock, F., Kitagawa, H., Van Der 927 Plicht, J., Schlolaut, G., Marshall, M. H., Brauer, A., Lamb, H. F., Payne, R. L., 928 Tarasov, P. E. Haraguchi, T., Gotanda, K., Yonenobu, H., Yokoyama, Y., Tada, 
929 R. and Nakagawa, T. 2012. A complete terrestrial radiocarbon record for 11.2 to $930 \quad 52.8$ kyr BP. Science, 338: 370-374

931

932 Cassidy, M., Watt, S. F., Palmer, M. R., Trofimovs, J., Symons, W., Maclachlan, 933 S. E. and Stinton, A. J. 2014. Construction of volcanic records from marine 934 sediment cores: A review and case study (Montserrat, West Indies). Earth935 Science Reviews, 138: 137-155

936

937 Chen, S. S., Lee, S. G., Lee, T. J., Lee, Y. S. and Liu, J. Q. 2018. Multi-stage 938 magmatic plumbing system of the volcano: A case study from Ulleung Island, 939 South Korea. Lithos. 314: 201-215

940

941 Chen, X. Y., Blockley, S. P., Tarasov, P. E., Xu, Y. G., McLean, D., Tomlinson, 942 E. L., Albert, P. G., Liu, J. Q., Müller, S., Wagner, M. and Menzies, M. A., 2016. 943 Clarifying the distal to proximal tephrochronology of the Millennium (B-Tm) 944 eruption, Changbaishan Volcano, northeast China. Quaternary Geochronology, 945 33: $61-75$

946

947 Chen X. Y., McLean, D., Blockley, S., Tarasov, P., Xu. Y. G. and Menzies, M. 948 2019. Developing a Holocene tephrostratigraphy for northern Japan using the 949 sedimentary record from Lake Kushu, Rebun Island, Quaternary Science 950 Reviews, 215: 272-292

951

952 Chun, J. H., Han, S. J. and Cheong, D. K., 1997. Tephrostratigraphy in the 953 Ulleung Basin, East Sea: Late Pleistocene to Holocene. Geosciences Journal, 954 1: 154-166 955

956 Chun, J. H., Cheong, D., Ikehara, K. and Han, S. J. 2007. Age of the SKP-I and 957 SKP-II tephras from the southern East Sea/Japan Sea: implications for 958 interstadial events recorded in sediment from marine isotope stages 3 and 4. 959 Palaeogeography, Palaeoclimatology, Palaeoecology, 247: 100-114 960 
961 Cui, Z. X., Wei, H. Q., Liu, R. X. 1995. Historical documentation research of

962 eruptions of the Tianchi volcano, Changbaishan. In: Liu, R.X. (Ed.), Volcanism and Human Environment. Seismology Press, Beijing, pp. 36-39 (In Chinese). 964

965 Derkachev, A.N., Utkin, I.V., Nikolaeva, N.A., Gorbarenko, S.A., Malakhova, 966 G.I., Portnyagin, M.V., Sakhno, V.G., Shi, X. and Lv, H. in press. Tephra layers 967 of large explosive eruptions of Baitoushan/Changbaishan Volcano in the Japan 968 Sea sediments. Quaternary International.

969 https://doi.org/10.1016/j.quaint.2019.01.043

970

971 Domitsu, H., Shiihara, M., Torii, M., Tsukawaki, S. and Oda, M. 2002.

972 Tephrostratigraphy of the piston cored sediment KT96-17 P-2 in the southern 973 Japan Sea: the eruption age of Daisen-Kusadanihara Pumice (KsP). Journal of 974 the Geological Society of Japan. 108: 545-556 (in Japanese with English 975 abstract)

976

977 Furuta, T., Fujioka, K. and Arai, F. 1986. Widespread submarine tephras around 978 Japan—petrographic and chemical properties. Marine Geology, 72: 125-142 979

980 Hakozaki, M., Miyake, F., Nakamura, T., Kimura, K., Masuda, K. and Okuno, M. 981 2017. Verification of the Annual Dating of the 10th Century Baitoushan Volcano 982 Eruption Based on an AD 774-775 Radiocarbon Spike. Radiocarbon, 60: 1-8 983

984 Higashino, T., Tsujimori T. and Itaya T. 2005. An alkaline tephra found at 985 Midagahara, Mt. Hakusan. 32. Annual Report Hakusan Nature Conservation 986 Center, 32: $1-7$ 987

988 Horn, S. and Schmincke, H. U. 2000. Volatile emission during the eruption of 989 Baitoushan Volcano (China/North Korea) ca. 969 AD. Bulletin of Volcanology, 990 61: 537-555

991

992 Hughes, P. D. M., Mallon, G., Brown, A., Essex, H. J., Stanford, J. D., Hotes, S. 993 2013. The impact of high tephra loading on late-Holocene carbon accumulation 
994 and vegetation succession in peatland communities. Quaternary Science

995 Reviews, 67: 160-175

996

997 lacovino, K., Ju-Song, K., Sisson, T., Lowenstern, J., Kuk-Hun, R., Jong-Nam, 998 J., Kun-Ho, S., Song-Hwan, H., Oppenheimer, C., Hammond, J. O. and 999 Donovan, A. 2016. Quantifying gas emissions from the "Millennium Eruption" of 1000 Paektu volcano, Democratic People's Republic of Korea/China. Science 1001 Advances, 2: 1600913

1002

1003

Ikehara, K. 2003. Late Quaternary seasonal sea-ice history of the North-eastern 1004 Japan Sea. Journal of Oceanography, 59: 585-593

1005

1006

Ikehara, K., Kikkawa, K., Chun, J. H. 2004. Origin and correlation of three 1007 tephras that erupted during oxygen isotope stage 3 found in cores from the 1008 Yamato Basin, central Japan Sea. The Quaternary Research. 43, 201-212 (in 1009 Japanese with English abstract)

1010

1011

Ikehara, K., Ohkushi, K., Noda, A., Danhara, T. and Yamashita, T. 2013. A new 1012 local marine reservoir correction for the last deglacial period in the Sanriku

1013 region, northwestern North Pacific, based on radiocarbon dates from the

1014 Towada-Hachinohe (To-H) tephra. The Quaternary Research. 52: 127-37 1015

1016 Im, J. H., Shim, S. H., Choo, C. O., Jang, Y. D. and Lee, J. S. 2012.

1017 Volcanological and palaeoenvironmental implication of charcoals of the Nari 1018 Formation in Nari Caldera, Ulleung Island, Korea. Geosciences Journal, 16: $1019 \quad 105-114$

1020

1021 Jochum, K. P., Stoll, B., Herwig, K., Willbold, M., Hofmann, A. W., Amini, M. et 1022 al., 2006. MPI-DING reference glasses for in situ microanalysis: New reference 1023 values for element concentrations and isotope ratios. Geochemistry,

1024 Geophysics, Geosystems, 7: 2 
1026 Kim, Y. K. 1985. Petrology of Ulreung Volcanic Island. The Journal of the

1027 Japanese Association of Mineralogists, Petrologists and Economic Geologists,

1028 80: 292-303

1029

1030 Kim, K. H, Tanaka T, Nagao K, Jang, S. K. 1999. Nd and Sr isotopes and K- Ar 1031 ages of the Ulreungdo alkali volcanic rocks in the East Sea, South Korea.

1032 Geochemical Journal, 33: 317-341

1033

1034 Kim, G. B., Cronin, S. J., Yoon, W. S. and Sohn, Y. K. 2014. Post 19 ka BP 1035 eruptive history of Ulleung Island, Korea, inferred from an intra-caldera pyroclastic sequence. Bulletin of Volcanology, 76: 802

1037

1038

1039

1040

1041

1042

1043

1044

1045

1046

1047

1048

1049

1050

1051

1052

1053 Kitagawa, H. and van der Plicht, H. 1998b. Atmospheric Radiocarbon

1054 Calibration to 45,000 yr B.P.: Late Glacial Fluctuations and Cosmogenic Isotope 1055 Production. Science, 279: 1187-1190

1056

1057 Kitagawa, H. and van der Plicht, J. 2000. Atmospheric radiocarbon calibration 1058 beyond 11,900 cal BP from Lake Suigetsu laminated sediments. Radiocarbon, 1059 42: 370-381 
1061 Le Bas, M. J., Le Maitre, R. W., Streckeisen, A. and Zanettin, B. 1986. A chemical classification of volcanic rocks based on the total alkali-silica diagram. Journal of petrology, 27: 745-750

1064

\section{5}

1066

1067

1068

1069

1070

1071

1072

1073

1074 1075 1082

Lim, C., Toyoda, K., Ikehara, K. and Peate, D.W. 2013. Late Quaternary tephrostratigraphy of Baegdusan and Ulleung volcanoes using marine sediments in the Japan Sea/East Sea. Quaternary Research, 80: 76-87

Lim, C., Kim, S. and Lee, C. 2014. Geochemical fingerprint of the primary magma composition in the marine tephras originated from the Baegdusan and Ulleung volcanoes. Journal of Asian Earth Sciences, 95: 266-273

Liu, R. X., Wei, H. Q., Li, J. T. 1998. The Latest Eruptions from Tianchi Volcano. Changbaishan. Science Press, Beijing, p. 159 (In Chinese)

Machida, H. and Arai, F. 1983. Extensive ash falls in and around the Sea of Japan from large late Quaternary eruptions. Journal of Volcanology and Geothermal Research, 18: 151-164

Machida, H. and Arai, F. 2003. Atlas of tephra in and around Japan. Revised ed. Tokyo University Press, Tokyo 
combination with thin-section microscopy, applied to the Late Glacial

1095 chronology from Lake Suigetsu, Japan. Quaternary Geochronology, 13: 70-80 1096

Martin-Jones, C. 2012. Defining fractionation in LA-ICP-MS analysis of volcanic 1098 glass shards and its application to the correlation of tephra deposits from

Ulleungdo, Korea (Doctoral dissertation, MPhil thesis, Aberystwyth University). 1100

McLean, D., Albert, P. G., Nakagawa, T., Staff, R. A., Suzuki, T. and Smith, 1106 V.C. 2016. Identification of the Changbaishan 'Millennium' (B-Tm) eruption deposit in the Lake Suigetsu (SG06) sedimentary archive, Japan: Synchronisation of hemispheric-wide palaeoclimate archives. Quaternary Science Reviews, 150: 301-307

McLean, D., Albert, P. G., Nakagawa, T., Suzuki, T., Staff, R. A., Yamada, K., Kitaba, I., Haraguchi, T., Kitagawa, J., Members, S.P. and Smith, V. 2018. Integrating the Holocene tephrostratigraphy for East Asia using a highresolution cryptotephra study from Lake Suigetsu (SG14 core), central Japan. Quaternary Science Reviews, 183: 36-58

Nagahashi, Y., Yoshikawa, S., Miyakawa, C., Uchiyama, T. and Inouchi, Y. 2004. Stratigraphy and chronology of widespread tephra layers during the past 430 ky in the Kinki District and the Yatsugatake Mountains: major element composition of the glass shards using EDS analysis. The Quaternary Research (Daiyonki-Kenkyu), 43: 15-35 (in Japanese with English abstract) 
1128 Lamb, H. and Suigetsu 2006 Project Members. 2012. SG06, a perfectly

1129 continuous and varved sediment core from Lake Suigetsu, Japan: stratigraphy

1130 and potential for improving the radiocarbon calibration model and

1131 understanding of late Quaternary climate changes. Quaternary Science

1132 Reviews, 36: 164-176

1133

1134 Nakajima, T., Kikkawa, K., Ikehara, K., Katayama, H., Kikkawa, E., Joshima, M., 1135 Seto, K. 1996. Marine sediments and late Quaternary stratigraphy in the 1136 southeastern part of the Japan Sea - Concerning the timing of dark layer 1137 deposition. Journal of Geological Society of Japan, 102: 125 - 138 (in 1138 Japanese with English abstract)

Newhall, C. G. and Self, S. 1982. The volcanic explosivity index (VEI) an 1141 1142 estimate of explosive magnitude for historical volcanism. Journal of Geophysical 1143

1153 Oppenheimer, C., Wacker, L., Xu, J., Galván, J. D., Stoffel, M., Guillet, S., 1154 Corona, C., Sigl, M., Di Cosmo, N., Hajdas, I. and Pan, B. 2017. Multi-proxy 1155 dating the 'Millennium Eruption' of Changbaishan to late 946 CE. Quaternary 1156 Science Reviews, 158: 164-171

1157

1158 Pan, B., de Silva, S.L., Xu, J., Chen, Z., Miggins, D.P. and Wei, H. 2017. The 1159 VEl-7 Millennium eruption, Changbaishan-Tianchi volcano, China/DPRK: New 1160 field, petrological, and chemical constraints on stratigraphy, volcanology, and 
magma dynamics. Journal of Volcanology and Geothermal Research, 343: 45-

116259

1163

1164 Park, M. H., Kim, I. S. and Shin, J. B. 2003. Characteristics of the late

1165 Quaternary tephra layers in the East/Japan Sea and their new occurrences in western Ulleung Basin sediments. Marine Geology, 202: 135-142

1167

Ponomareva, V., Polyak, L., Portnyagin, M., Abbott, P. M., Zelenin, E.,

Vakhrameeva, P. and Garbe-Schönberg, D. 2018. Holocene tephra from the

1174 Chukchi-Alaskan margin, Arctic Ocean: Implications for sediment chronostratigraphy and volcanic history. Quaternary Geochronology, 45: 85-97

1176

Reimer, P. J., Bard, E., Bayliss, A., Beck, J. W., Blackwell, P. G., Ramsey, C. B., Buck, C. E., Cheng, H., Edwards, R. L., Friedrich, M. and Grootes, P.M. 2013. IntCal13 and Marine13 radiocarbon age calibration curves 0-50,000 1181 years cal BP. Radiocarbon, 55: 1869-1887

Sawada, Y., Nakamura, T., Umeda, Y., Yoon, S. and Tokuoka. 1997. Drifting 1186 pumice clasts derived from Ulleung Island in early Holocene sediments at Oda, Shimane Prefecture, Southwestern Japan. The Quaternary Research (DaiyonkiKenkyu), 36: 1 - 16 (in Japanese with English abstract)

1193 Shiihara, M., Torii, M., Okuno, M., Domitsu, H., Nakamura, T., Kim, K., 1194 Moriwaki, H. and Oda, M. 2011. Revised stratigraphy of Holocene tephras on 
1195 Ulleung Island, South Korea, and possible correlatives for the U-Oki tephra.

Singer, B. S., Jicha, B. R., He, H. and Zhu, R. 2014. Geomagnetic field excursion recorded $17 \mathrm{ka}$ at Tianchi volcano, China: New ${ }^{40} \mathrm{Ar} /{ }^{39} \mathrm{Ar}$ age and

1200 significance. Geophysical Research Letters, 41: 2794-2802

1201

1202 Smith, V. C., Mark, D. F., Staff, R. A., Blockley, S. P. E., Bronk-Ramsey, C., 1203 Bryant, C. L., Nakagawa, T., Han, K. K., Weh, A., Takemura, K., Danhara, T. 1204 and Suigetsu 2006 Project Members. 2011. Toward establishing precise Ar/Ar chronologies for Late Pleistocene palaeoclimate archives: an example from the 1208 1209 Lake Suigetsu (Japan) sedimentary record, Quaternary Science Reviews, 30: $2845-2850$

1214

1215 Staff, R. A., Bronk Ramsey, C., Bryant, C. L., Brock, F., Payne, R. L., Schlolaut, 1216 G., Marshall, M. H., Brauer, A., Lamb, H. F., Tarasov, P., Yokoyama, Y., 1217 Haraguchi, T., Gotanda, K., Yonenobu, H., Nakagawa, T. and Suigetsu 2006 1218 project members. 2011. New 14C determinations from Lake Suigetsu, Japan: 12,000 to 0 cal. BP, Radiocarbon, 53: 511-528

1220

1221 Staff, R. A., Schlolaut, G., Ramsey, C. B., Brock, F., Bryant, C. L., Kitagawa, H., 1222 Van der Plicht, J., Marshall, M. H., Brauer, A., Lamb, H. F. and Payne, R. L. 1223 2013a. Integration of the old and new Lake Suigetsu (Japan) terrestrial radiocarbon calibration data sets. Radiocarbon, 55: 2049-2058

1225

1226 Staff, R. A., Nakagawa, T., Schlolaut, G., Marshall, M.H., Brauer, A., Lamb, H.

1227 F., Bronk Ramsey, C., Bryant, C. L., Brock, F., Kitagawa, H. and Plicht, J., 
2013b. The multiple chronological techniques applied to the Lake Suigetsu SG06 sediment core, central Japan. Boreas, 42: 259-266

1230

1231 Stone, R. 2010. Is China's riskiest volcano stirring or merely biding its time?

1232 Science, 329: 498-499

1233

1234 Sun, S. S. and McDonough, W. F. 1989. Chemical and isotopic systematics of

1235 oceanic basalts: implications for mantle composition and processes. Geological

1236 Society, London, Special Publications, 42: 313-345

1237

1238 Sun, C., Plunkett, G., Liu, J., Zhao, H., Sigl, M., McConnell, J. R., Pilcher, J. R., 1239 Vinther, B., Steffensen, J. P. and Hall, V. 2014a. Ash from Changbaishan

1240 Millennium eruption recorded in Greenland ice: Implications for determining the 1241 eruptions timing and impact. Geophysical Research Letters, 41: 694-701 1242

1243 Sun, C., You, H., Liu, J., Li, X., Gao, J. and Chen, S. 2014b. Distribution, 1244 geochemistry and age of the Millennium eruptives of Changbaishan volcano, 1245 Northeast China-A review. Frontiers of Earth Science, 8: 216-230 1246

1247 Sun, C., You, H., He, H., Zhang, L., Gao, J., Guo, W., Chen, S., Mao, Q., Liu, 1248 Q., Chu, G. and Liu, J., 2015. New evidence for the presence of Changbaishan 1249 Millennium eruption ash in the Longgang volcanic field, Northeast China.

1250 Gondwana Research, 28: 52-60

1251

1252 Sun, C., Liu, J., You, H. and Nemeth, K. 2017. Tephrostratigraphy of

1253 Changbaishan volcano, northeast China, since the mid-Holocene. Quaternary 1254 Science Reviews, 177: 104-119

1255

1256 Sun, C., Wang, L., Plunkett, G., You, H., Zhu, Z., Zhang, L., Zhang, B., Chu, G. 1257 and Liu, J. 2018. Ash from the Changbaishan Qixiangzhan eruption: A new 1258 early Holocene marker horizon across East Asia. Journal of Geophysical 1259 Research: Solid Earth, 123: 6442-6450

1260 
1261 Tada, R. 1999. Late Quaternary paleoceanography of the Japan Sea. The

1262 Quaternary Research (Daiyonki-Kenkyu), 38: 216-222

1263

1264 Tada, R., Irino, T. and Koizumi, I. 1999. Land-ocean linkages over orbital and

1265 millennial timescales recorded in Late Quaternary sediments of the Japan Sea.

1266 Paleoceanography, 14: 236-247

1267

1268

1269

1270

1271

1272

1273

1274

1275

1276

1277

1278

1279

1280

1281

1282

1283

1284

1285

1286

1287

1288

1289

1290

1291

1292

Wan, J. and Zheng,

D. 2000 volcanic rocks by FT method-illustrated by dating of Changbaishan volcanic rocks. Seismology and Geology, 22: 19-24 (In Chinese with English abstract)

1293

Tomlinson, E. L., Albert, P. G., Wulf, S., Brown, R. J., Smith, V. C., Keller, J., Orsi, G., Bourne, A. J. and Menzies, M. A. 2014. Age and geochemistry of tephra layers from Ischia, Italy: constraints from proximal-distal correlations with Lago Grande di Monticchio. Journal of Volcanology and Geothermal Research, 287: $22-39$

Turney, C.S., 1998. Extraction of rhyolitic component of Vedde microtephra from minerogenic lake sediments. Journal of Paleolimnology, 19: 199-206

Tsukui, M., Saito, K. and Hayashi, K. 2006. Frequent and intensive eruptions in the 9th century, Izu Islands, Japan: Revision of volcano-stratigraphy based on tephras and historical document. Bulletin of Volcanological Society of Japan, 1: 327-338 
1294 Wei, H., Liu, G. and Gill, J. 2013. Review of eruptive activity at Tianchi volcano, 1295 Changbaishan, northeast China: implications for possible future eruptions.

1296 Bulletin of Volcanology, 75: 706

1297

1298 Wulf, S., Kraml, M., Brauer, A., Keller, J. and Negendank, J.F. 2004.

1299 Tephrochronology of the 100 ka lacustrine sediment record of Lago Grande di

1300 Monticchio (southern Italy). Quaternary International, 122: 7-30

1301

1302 Xu, J., Liu, G., Wu, J., Ming, Y., Wang, Q., Cui, D., Shangguan, Z., Pan, B., Lin, 1303 X. and Liu, J. 2012. Recent unrest of Changbaishan volcano, northeast China:

1304 A precursor of a future eruption? Geophysical Research Letters, 39: 16 1305

1306 Yang, L., Wang, F., Feng, H., Wu, L. and Shi, W. 2014. ${ }^{40} \mathrm{Ar} /{ }^{39} \mathrm{Ar}$ geochronology 1307 of Holocene volcanic activity at Changbaishan, Northeast China. Quaternary 1308 Geochronology, 21: $106-114$

1309

1310 Zou, H., Fan, Q., Zhang, H. 2010. Rapid development of the great millennium 1311 eruption of Changbaishan (Tianchi) volcano, China/North Korea: evidence from 1312 U-Th zircon dating. Lithos, 119: 289-296 





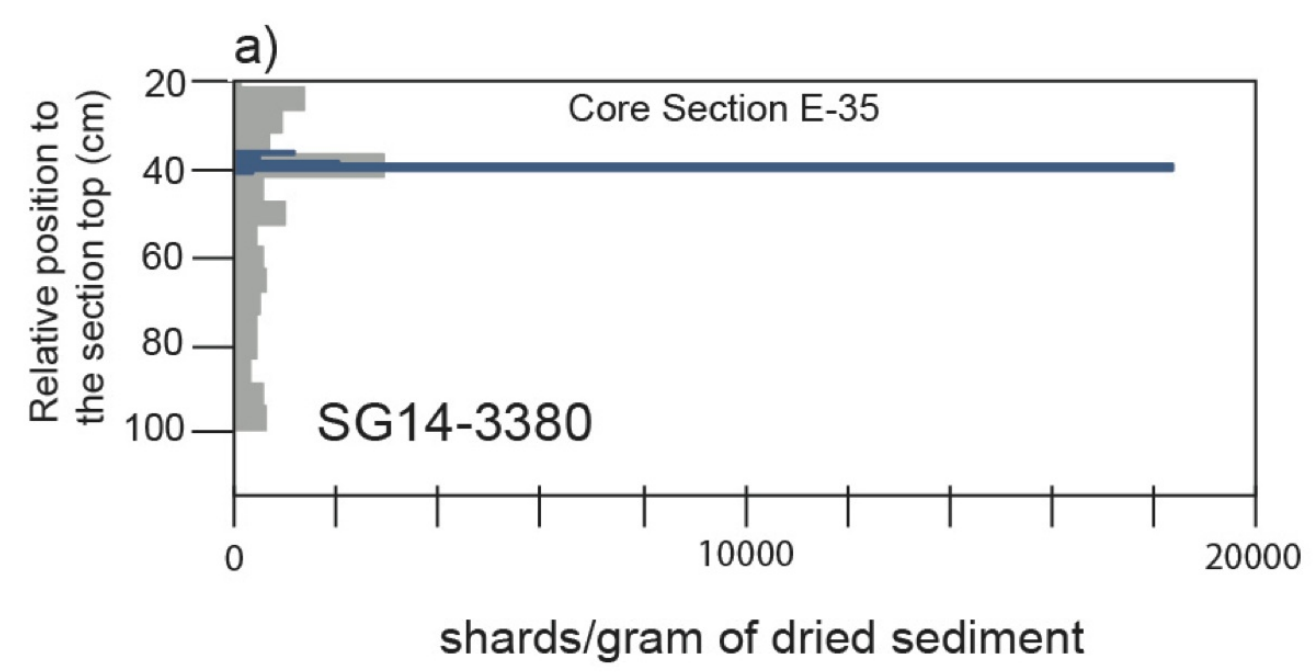

b)

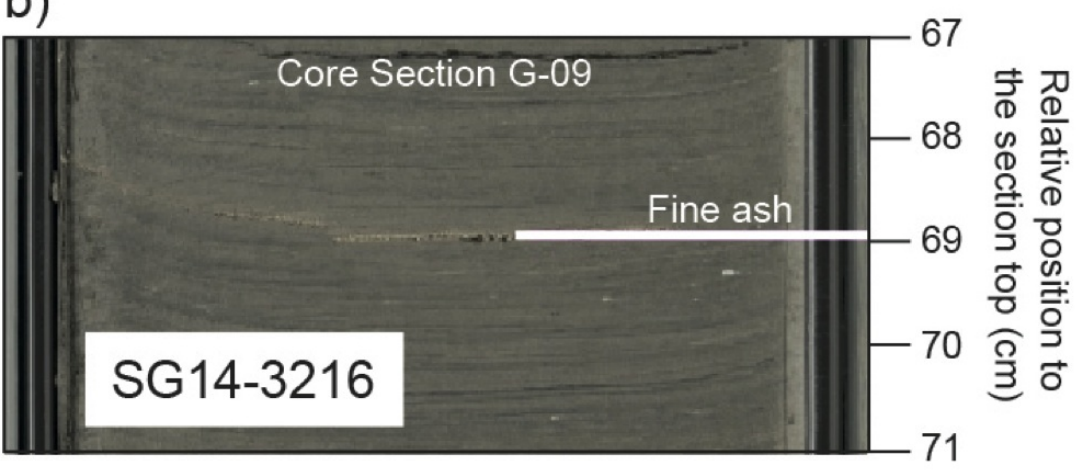

shards/gram of dried sediment 

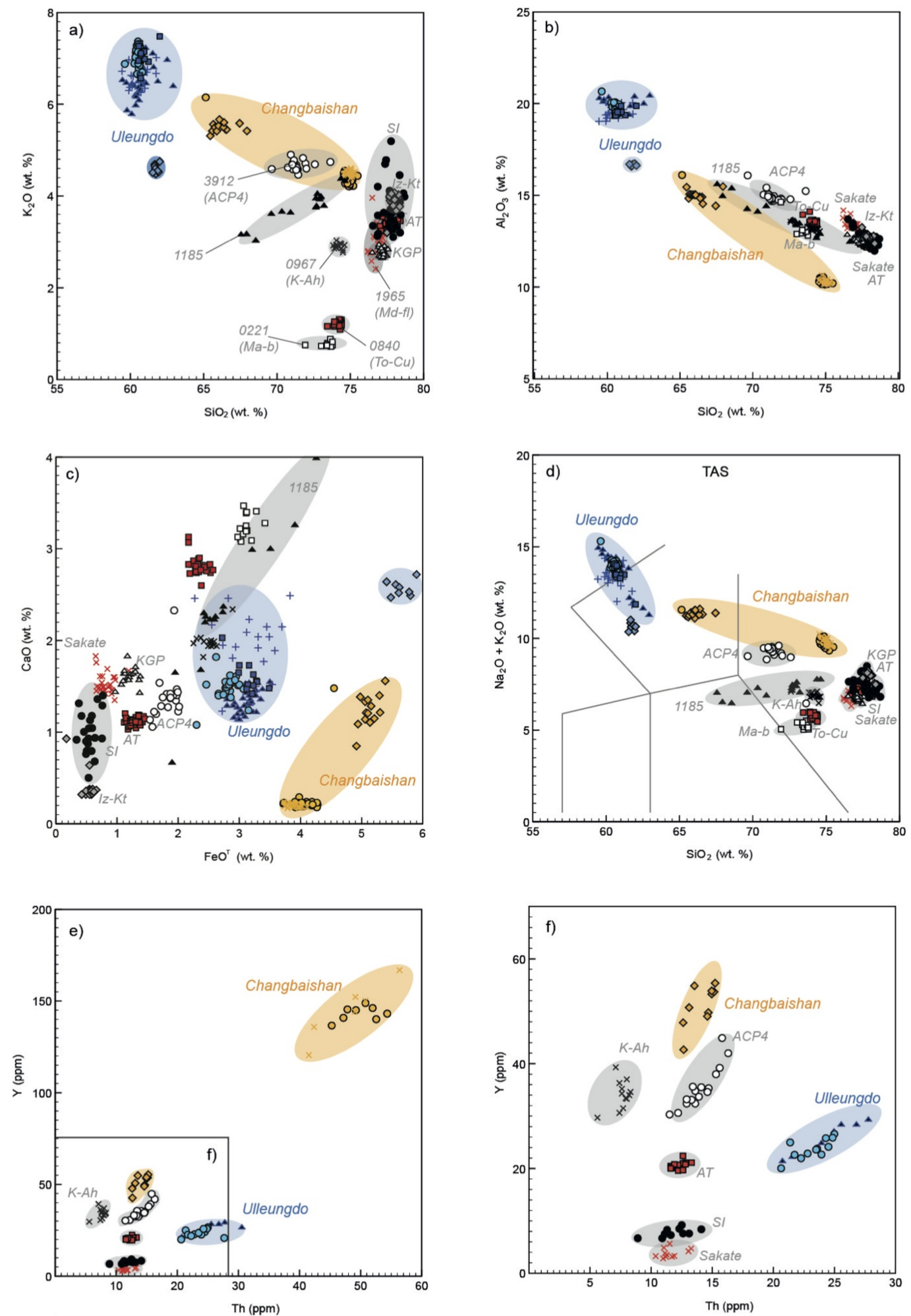

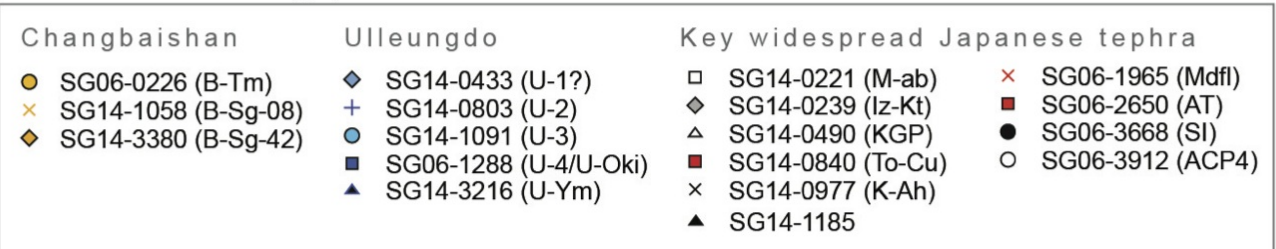




